NBER WORKING PAPER SERIES

\title{
ELECTED VERSUS APPOINTED POLICYMAKERS: EVIDENCE FROM CITY TREASURERS
}

\author{
Alexander Whalley \\ Working Paper 15643 \\ http://www.nber.org/papers/w15643 \\ NATIONAL BUREAU OF ECONOMIC RESEARCH \\ 1050 Massachusetts Avenue \\ Cambridge, MA 02138 \\ January 2010
}

I thank Leah Brooks, Richard Boylan, Tom Hansford, Shawn Kantor, Josh Kinsler, Stephan Litschig, John Matsusaka, Kevin Milligan, Enrico Moretti, Ronnie Pavan, Lori Raineri, Todd Sorenson, Guido Tabellini, Jessica Trounstine, Gergely Ujhelyi, Christine Vuletich, Kelley Williams and seminar participants at the Canadian Public Economics Group, Texas A \& M University, the University of California Merced, the University of Houston/Rice University, the University of Rochester, and the University of Virginia for helpful comments and discussions. Matt Siordia and Chris Abrescy provided outstanding research assistance. All errors are my own. The views expressed herein are those of the author and do not necessarily reflect the views of the National Bureau of Economic Research.

NBER working papers are circulated for discussion and comment purposes. They have not been peerreviewed or been subject to the review by the NBER Board of Directors that accompanies official NBER publications.

(C) 2010 by Alexander Whalley. All rights reserved. Short sections of text, not to exceed two paragraphs, may be quoted without explicit permission provided that full credit, including $\bigcirc$ notice, is given to the source. 
Elected Versus Appointed Policymakers: Evidence from City Treasurers

Alexander Whalley

NBER Working Paper No. 15643

January 2010

JEL No. D7,H1,H7

\begin{abstract}
$\underline{\text { ABSTRACT }}$
This paper investigates whether methods of public official selection affect policymaking in cities. I draw on the unique characteristics of California's city referendum process to identify the causal effect of city treasurers' method of selection on their cities' debt management policies. I utilize a regression discontinuity strategy based on the effect of narrowly-passing appointive city treasurer referendums on city borrowing costs. The results indicate that appointive treasurers reduce a city's cost of borrowing by $13 \%$ to $23 \%$. The results imply that if all cities in California with elected treasurers were to appoint them, total borrowing expenditures would be reduced by more than $\$ 20$ million per year. Appointive city treasurers appear to reduce borrowing costs primarily through the refinancing of expensive debt at lower interest rates.
\end{abstract}

\author{
Alexander Whalley \\ School of Social Sciences, Humanities and Arts \\ University of California, Merced \\ 5200 N. Lake Road \\ Merced, CA 95343 \\ and NBER \\ awhalley@ucmerced.edu
}




\section{Introduction}

Understanding how political institutions affect policy outcomes has long been a central issue in economics. ${ }^{1}$ Many differences in political institutions center on how leaders are selected and held accountable. In this paper, I compare the policy choices of public officials who are selected and held accountable in very different ways - bureaucrats and politicians - for the case of city treasurers.

The case of case of city treasurers is particularly compelling to examine for two reasons. First, as both elected and appointed city treasurers' are responsible for debt management policy, the differences in costs cities pay to borrow provide a clear measure of different debt management policy choices. ${ }^{2}$ Second, quasi-experimental variation in the method of selection for city treasurers is available from votes on city referendums, allowing for concerns about the endogeneity of institutions to be effectively addressed. The context of city treasurers provides a rare opportunity to examine whether differences public official selection methods actually cause meaningful differences in policymaking.

Methods of public official selection can affect policymaking through the competence and effort policymakers supply to the policy task (e.g. Besley, 2006). Recent theoretical contributions argue that bureaucrats have a comparative advantage in technical policymaking (see for example Maskin and Tirole, 2004; Alesina and Tabellini, 2007, 2008; and Vlaicu, 2008). Empirically the most compelling evidence that shows politicians choose policies more favorable towards voters. Besley and Coate (2003) find that elected electricity rate regulators choose lower prices than appointed regulators. Besley and Payne (2006) find that more employment discrimination lawsuits are submitted when a judge is elected rather then appointed. ${ }^{3}$

\footnotetext{
${ }^{1}$ Besley and Case (2003) provide an excellent survey of the literature.

${ }^{2}$ Treasurers are also allocated the primary tasks of the receipt and safekeeping of public money coming into the Treasury, compliance with laws governing the deposit and paying out of public money, and submission to the city council of a monthly report accounting for all revenue, expenses, and balances in city accounts. Treasurers may also be in charge of collection of city revenues, as well as, cash flow and investment policy for city funds. See CMTA (2001) for further details. City treasurers are not responsible for city fiscal policy or the decision to borrow however.

${ }^{3}$ There is large literature on the effects of appointed and elected regulators that has generally found mixed results. The mixed findings in the earlier literature are likely due to not addressing the institutional endogeneity issue as carefully as the more recent studies. See Besley and Coate (2003) for an excellent survey of the prior literature.
} 
Whether the empirical evidence squares with the theoretical arguments remains an open question. It is unclear, for example, whether evidence from electricity rate regulation and judicial decision making outcomes primarily reflects differences in public official policy performance or differences in pandering to public opinion. In this paper I study the appointive effect for a different technical policy issue, one where policy choices affect the cost of a specific government service and closely reflect public official policy performance. The results of my analysis inform the debate about whether the theoretical predictions of recent models line up closely with the empirical evidence.

Beside an obvious interest for political economists, the existence of policy outcome and performance differentials between elected and appointed officials has tremendous practical relevance. In particular, with many cities spending substantial sums to service their debt every year, improved debt management policy could well increase government efficiency. As Arthur Levitt, the former chairmen of the Securities and Exchange Commission, writes:

"State, county and municipal entities across the nation enjoy a privileged position in the debt markets - the interest they pay is often tax-free and their market is lightly regulated. So, how is it possible that local entities frequently pay too much to borrow money?... Many elected and appointed officials simply don’t care... Taxpayers should be irate." Levitt (2009).

The key empirical challenge faced in estimating the appointive effect is to disentangle the effect of city treasurer selection methods on policy choices from other determinants of city borrowing costs. One central factor that affects city borrowing costs is default risk. Factors that affect default risk, such as the level of city debt or the economic conditions of the local economy, may well affect the choice of city treasurer selection methods. For example, as the benefits of effective debt management policy are especially large for cities with large amounts of debt these cities may be more likely to choose city treasurer selection methods resulting in lower borrowing costs. As cities with large levels of debt are subject to more default risk, these cities are likely to pay higher borrowing costs anyway. Furthermore, as many components of default risk are frequently unobserved, city treasurer selection methods are likely to be endogenously related to the unobserved default risk of a city. ${ }^{4}$

The central contribution of this paper is to estimate the causal effect of bureaucratic ver-

\footnotetext{
${ }^{4}$ See Besley and Case (2003) and Acemoglu (2005) for discussions on the implications of endogenous institutions for estimating the causal effect of institutions. Aghion, Alesina, and Trebbi (2004) and Acemoglu, Ticchi and Vindigni (2006) introduce theoretical models of the endogenous determination of institutions.
} 
sus political selection methods on policymaking. I implement a regression discontinuity (RD) research design to estimate the causal effect of city treasurer selection methods on city borrowing costs. ${ }^{5}$ The design takes advantage of the unique characteristics of California's local referendum process to isolate quasi-experimental variation in city treasurer selection methods. Many differences in city treasurer selection methods across cities are likely due to differences in unobserved city institutions, resident preferences, or special interest strength that also likely affect borrowing costs. Cities where residents vote to pass an appointive city treasurer referendum may well differ on both observable and unobservable dimensions from those that do not. However, cities in which an appointive treasurer referendum passes by a very narrow margin are likely to be quite similar on average to cities where an appointive treasurer referendum fails by a very narrow margin. Taking advantage of this feature, I use a regression discontinuity research design to identify the causal effect of city treasurer selection methods on city borrowing costs. I apply this estimator to a newly available rich data set from cities in California combining over a decade of information on local referendums with annual measures of city borrowing costs.

My main results concern the treasurer appointive effect on city borrowing costs. I find that having an appointed rather than elected city treasurer reduces city borrowing costs by between $13 \%$ and $23 \%$. The results imply that if all cities in California with elected treasurers were to appoint them, total borrowing expenditures would be reduced by $\$ 20$ million per year. These effects do not appear to be driven by other unobserved determinants of borrowing costs discontinuously changing at the threshold of referendum passage. In addition, I find little evidence that either fiscal policy or other costs of borrowing are affected by the method of selection for the city treasurer.

I also examine whether the appointive effect is primarily due to differences in debt restructuring policy or debt issuance policy choices. Reducing borrowing costs with debt restructuring policies requires active monitoring of public debt markets, as well as, the expertise to evaluate likely changes future market interest rates. Reducing borrowing costs with debt issuance policies, in contrast, requires the use of competitive debt sales that reduce payments to (potentially politically connected) financial intermediaries. As debt restructuring policies require more treasurer effort and expertise than debt issuance policies, understanding the channel for the appointive effect provides evidence on the importance of treasurer supplied inputs in explaining

\footnotetext{
${ }^{5}$ Several previous papers have used elections as sources of identification in regression discontinuity models. See for example, Lee (2008), Ferreira and Gyourko (2009), and Cellini, Ferreira, and Rothstein (2008). Lee and Lemeuix (2008) and Angrist and Pischke (2009) provide excellent surveys of the regression discontinuity research design.
} 
the central findings.

I separately measure debt restructuring and debt issuance policy choice differences by using cross-sectional debt issue level data containing information on the date of the debt issue, in addition to, the interest rate. Information on the date that the debt is issued is useful in disentangling the two types of policies, as debt issuance policies are chosen by the treasurer in office at the time the debt is issued. Thus, differences in debt restructuring policies can be measured by differences in borrowing costs for debt issued before the referendum as high interest rate debt issues are selectively retired. Similarly, differences in debt issuance policies can be measured by the appointive effect on debt issued after the referendum. The evidence indicates that the appointive effect is primarily due to debt restructuring, but not debt issuing policies.

More broadly this paper also contributes to recent literature on the effects of electoral accountability and leader selection on policymaking and public goods provision. Recent empirical work has demonstrated the important role for electoral accountability in policymaking and the provision of public goods in a variety of contexts (Besley and Case, 1995; List and Sturm, 2006; and Ferraz and Finan, 2007, 2008). It has also been shown that leadership change has an important effect on institutional and economic performance (Jones and Olken, 2005).

My results provide clear evidence that bureaucratic control of city debt management policy reduces city borrowing costs. Caution is required, however, in attempting to generalize these results beyond my context and sample. Even within my sample, effects may differ for cities not at the margin in passing an appointive treasurer referendum. Nevertheless, finding that bureaucratic control of debt management policy reduces city borrowing costs is an important result that provides empirical support for recent theoretical work emphasizing the comparative advantage of bureaucratic control for technical policymaking (Maskin and Tirole, 2004; Alesina and Tabellini, 2007, 2008; and Vlaicu, 2008).

The remainder of the paper is organized as follows: Section 2 describes the context and empirical approach. Section 3 describes the data and descriptive statistics. Section 4 presents the main results and validates the research design. Section 5 examines evidence of differences in debt restructuring and issuance policy choices between politician and bureaucrat treasurers. Section 6 concludes. 


\section{Context and Empirical Approach}

\subsection{City Treasurers, Policy Choices, and City Borrowing Costs}

In this section I provide a brief overview of the operation of public debt markets, the role of city treasurers in city government, and debt management policies which affect borrowing costs.

There are three sets of participants in public debt markets: city issuers, financial intermediaries, and investors. The debt issuing process begins with the city deciding that a capital project (or other need) requires financing, financial intermediaries are then hired, the issue is then presented to the debt rating agencies, and finally the issue is sold to investors. ${ }^{6}$

City Treasurers City treasurers are delegated the tasks of managing public funds in accordance with the law (CMTA, 2001). They are primarily delegated the tasks of developing debt management, accounting, and cash management policies to implement legislative policy. The city treasurer influences city borrowing costs by their choice of debt management policies. ${ }^{7}$

Appointed and elected treasurers are likely to differ in the level of expertise and effort the supply to the policy task. In terms of expertise, the only requirements for a person to be an elected city treasurer is that they are a resident of the city, and usually, do not have a criminal conviction. In contrast, appointed city treasurers can be selected for their expertise in managing public debt. This difference often results in appointed treasurers having higher levels of education (often an MBA or MPP degree) than elected treasurers. ${ }^{8}$ In terms of effort, elected and appointed treasurers face very different returns to effort as the effect of policy performance on reelection for the politician and promotion for the bureaucrat are likely to be quite different. These effort differences crucially hinge on how well voters can observe policy performance by the politician and how city managers use policy performance to hire, fire, and promote bureaucrats

\footnotetext{
${ }^{6}$ For a more detailed discussion of the issuance laws, rules, and regulations which govern the process of public debt for cities in California see CDIAC (2006). For a more general discussion of public debt issuance and management by local governments see Joseph (1994) and Leonard (2004). See Feldstein and Fabozzi (2008) for an excellent and very thorough overview of the municipal debt market.

${ }^{7}$ These policies are sometimes chosen in a committee rather than by the city treasurer alone, but the city treasurer often plays a large role in setting the policy agenda regardless.

${ }^{8} \mathrm{I}$ have attempted to directly collect information on individual city treasurer education levels from cities themselves under a Public Records Act request. Unfortunately, many cities only keep very limited records on the educational qualifications of their treasurers, and the resulting data set is too incomplete to be useful.
} 
(Alesina and Tabellini, 2007).

City Borrowing Costs The cost that a city ultimately pays to finance a debt issue is composed of two factors: (1) the interest rate that investors demand to hold the debt and; (2) the spread between the interest rate spot price investors demand and what the city pays. The interest rate that investors require to hold the city debt depends principally on the default risk of a city. ${ }^{9}$ Aspects of the local economy and city fiscal policy affect default risk, and are reflected in the city debt rating. These factors can range from the diversity of the tax base, to whether city expenditure policies are sustainable, etc. In addition, other aspects of a debt issue such as the term length of the issue, and the principal amount affect borrowing costs. The characteristics of the debt issue are often determined by the nature of the project to be funded. However, the spread that a city pays above the spot market price for a debt issue depends on two debt management policies: debt issuance and debt restructuring.

Debt Issuance Policies Debt issuance policies primarily affect the spread that intermediaries receive. The key debt issuance policy choice is whether to sell the debt in a competitive auction, where sealed bids are submitted by underwriters and the lowest bid is chosen, or as a negotiated sale with a single underwriter chosen in advance of pricing. Competitive sales lead to lower borrowing costs for the issuer, but likely a smaller spread for the underwriter. ${ }^{10}$ Other debt issuance policy choices include when to issue the debt, and the characteristics of the debt issue such as term length etc.

Debt Restructuring Policies Debt restructuring policies are the second type of policies that can influence borrowing costs. City debt, much like conventional mortgages, can be refinanced. As market interest rates fluctuate according to many factors, refinancing when it is worthwhile to do so can result in lower average borrowing costs on city debt. The potential benefit of

\footnotetext{
${ }^{9}$ Municipal defaults are rare, but not unheard of. There were over 2000 defaults by cities and incorporated townships in the United States between 1939 and 1969 (Spiotto, 2008). Historically defaults have been due to provision of nonessential services, fraud and mismanagement, adverse local economic conditions, and natural or man-made disasters (Spiotto, 2008).

${ }^{10}$ The evidence is very clear on this difference in borrowing costs. See Robbins and Simonson (2007) and Simonson, Robbins and Helgerson (2001) for recent studies showing that competitive sales reduce borrowing costs for cities. Levitt (2009) criticizes non-competitive sales as 'pay to play' rewards for the campaign finance provided to elected officials by financial intermediaries
} 
refinancing a debt issue is expressed nicely in the municipal finance saying: "While doctors bury their mistakes, in municipal financing, they are refunded [refinanced]." Spiotto, 2008 p. 707.

As Figure 1 demonstrates there is significant variability in the market interest rate for municipal securities. There are predictable patterns of demand for an issue depending on the timing other issues from the U.S. Treasury and other large issuers, national holidays, seasonal demand from investors, etc. Unexpected changes in monetary or tax policy may also affect the cost of borrowing.

A debt refinancing policy of responding to favorable market conditions can significantly reduce average borrowing costs. For example, in a typical year a city treasurer who sells a revenue anticipation note on a week in the top $10 \%$ of the interest rate distribution will pay a 22 percent higher interest rate than one who sells the note in the bottom $10 \%$. While it is possible that refinancing may result in some characteristics of the debt issue the residents may value changing, the fact refinancing opportunities are primarily driven by the variation in market interest rates over time that all treasurers face suggests that changes in characteristics are likely to be second order.

\subsection{Empirical Approach}

The fundamental identification problem in generating unbiased estimates of a pure appointive effect on policy outcomes is that cities do not choose political institutions randomly. For a start, cities may well choose political institutions to maximize local social welfare. For example, as the benefit of a low cost debt management policy increases with the city debt level, cities with higher levels of debt may be more likely to choose treasurer selection methods that lead to the lower costs of borrowing. However, the size of the city debt is also likely to affect city borrowing costs anyway. In addition, many factors that influence both borrowing costs and the choice of political institutions are frequently unobserved. Therefore, a naive comparison of borrowing costs between cities with and without appointed treasurers may well lead to biased estimates

of the appointive effect. Credible estimates require variation in the method of selection for city treasurers which is independent of other unobserved factors that affect city policy outcomes.

Ordinary Least Squares To provide a benchmark for the regression discontinuity (RD) analysis that addresses the issue of institutional endogeneity I first estimate the appointive 
effect by ordinary least squares (OLS). The simple model I estimate can be expressed as,

$$
Y_{i t}=\text { sappointed }_{i t}+X_{i} \beta+\omega_{t}+\epsilon_{i t}
$$

where $i$ indexes the referendum and $t$ indexes the year. The variable appointed $_{i t}$ is a dummy variable that takes a value of one if the treasurer is appointed and value zero otherwise. $X_{i}$ is a vector of covariates from the 1990 census in the city where the referendum occurs, $\omega_{t}$ is a set of year fixed effects, and $\epsilon_{i t}$ is the error term. The variables I control for in the $X_{i}$ vector to capture variation in default risk across cities are: Income Per Capita,Population Size, Percentage White, Percentage Black, Percentage Less Than Seventeen, Percentage Greater Than SixtyFive, Percentage College Graduate, Percentage High School Graduate, Mayor-Council Form of Government, and Employment-Population Ratio. The conditional mean difference in policy outcomes between appointed and elected treasurers is reflected by $\delta$.

While it is possible to control for many easily measured city characteristics in the $X_{i}$ vector there are many unobserved components of borrowing costs. For example, cities may differ in their budgetary institutions that can affect the level of debt and probability of default. Poterba (1994) provides evidence that budgetary institutions affect debt levels and the adjustment to fiscal shocks for US states. Other factors such as the strategic use of debt by politicians (Alesina and Tabelinni, 1990) or high spending city legislative institutions (Coate and Knight, 2009) may lead to substantial debt accumulation and high borrowing costs. Differences in cities in these factors may well influence treasurer selection method choices in a city. In addition, poor performance by an elected treasurer may well lead city residents to push for a change in the treasurer selection method. To address concerns about correlations of treasurer selection methods with important unobservables I also estimate a regression discontinuity specification.

Regression Discontinuity Estimation Strategy To address the concern that treasurer method of selection may be endogenous related to other determinants of city borrowing costs I use a regression discontinuity (RD) strategy to compare cities where an appointive treasurer referendum barely passed to cities where an appointive treasurer referendum barely failed.

To understand how this strategy addresses concerns about the endogeneity of political institutions consider a city where residents vote on treasurer appointive referendum $i$, and the referendum receives vote share $s_{i}$. A referendum passes if it receives a vote share of greater than 0.5 so an indicator variable for the referendum passage can be expressed as: pass $_{i}=1\left(s_{i}>0.5\right)$. 
We can then express a post-referendum city policy outcome $\left(Y_{i}\right)$ as,

$$
Y_{i}=\alpha+\delta \text { pass }_{i}+\epsilon_{i}
$$

where $\delta$ is the causal effect of an appointed treasurer relative to an elected treasurer on the policy outcome, and $\epsilon_{i}$ represents all other determinants of $Y_{i}$. This simple model would yield an unbiased estimate of the appointive effect if the referendum outcome, pass $s_{i}$, was uncorrelated with the other determinants of policy, $\epsilon_{i}$. However, as many of the unobserved determinants of borrowing costs are likely reflected in voter preferences there are good reasons to suspect that the referendum outcome may well be correlated with other determinants of borrowing costs. If so, a simple regression of model (2) will yield a biased estimate of $\delta$. However, one can identify the causal effect of referendum passage by using the referendums that are barely rejected to form a counterfactual for the referendums that barely pass. Lee (2008) demonstrates that this strategy provides quasi-random variation in referendum outcomes, because for narrowly decided referendums, whether the referendum passes is likely to be determined by pure chance as long as there is some unpredictable component of the ultimate vote.

The implementation of the RD strategy I focus on here uses all of the referendums but controls the variation coming from non-close referendums using flexible controls for the vote share. ${ }^{11}$ Assuming that the conditional expectation of the unobserved determinants of $Y_{i}$ given the realized vote share, is continuous, we can approximate it by a polynomial of order $g$.

To implement my regression discontinuity approach I estimate models of the following form for each policy outcome, $Y_{i t}$,

$$
Y_{i t}=\delta \text { pass }_{i t}+P_{g}\left(s_{i}\right)+X_{i} \beta+\omega_{t}+\epsilon_{i t},
$$

where $i$ indexes the focal referenda and $t$ indexes the year. The variable pass $s_{i t}$ is a dummy variable that takes a value of one in every year after the referendum passes and value zero otherwise. $\mathrm{P}_{g}\left(\mathrm{~s}_{i}\right)$ is a polynomial function of the referenda vote share, $s_{i}$, of order $g . X_{i}$ is a vector of covariates from the 1990 census in the city where the referendum occurs, $\omega_{t}$ is a set of year fixed effects, and $\epsilon_{i t}$ is the error term. Again, the variables I control for in the $X_{i}$ vector to capture variation in default risk across cities are: Income Per Capita, Population Size, Percentage White, Percentage Black, Percentage Less Than Seventeen, Percentage Greater Than SixtyFive, Percentage College Graduate, Percentage High School Graduate, Mayor-Council Form of

\footnotetext{
${ }^{11}$ The RD design can be estimated parametrically or non-parametrically, focusing on only close elections or the larger sample of all elections. I follow a parametric approach using all referendums because it allows straightforward hypothesis testing, and precise estimates. See Lemeuix and Lee (2008) for a detailed comparison of alternative approaches to estimating RD models.
} 
Government, and Employment-Population Ratio. Thus, the appointive effect, $\delta$, is estimated controlling for the percent voting in favor with a flexible polynomial functional form.

The central identifying assumption for $\delta$ to estimate the causal effect of treasurer method of selection on policy outcomes is that all relevant factors vary smoothly at the referendum passage threshold. We need this assumption for city policy outcomes after a narrowly failing referendum to form an adequate counterfactual for city policy outcomes after a referendum narrowly passes. While this assumption is not testable directly, I examine whether city policy outcomes are smooth, conditional on the polynomial in vote share, in the years prior to referenda to assess its plausibility.

To estimate (3) I use all the post referendum data for a focal referendum in a given city. Observations are uniquely identified by the city and the date of the referendum. For the cities that have more than one referendum the same calendar year observation is used more than once. $^{12}$ To address this issue I follow Cellini, Ferreira, and Rothstein (2009) and cluster the standard errors at the city level to account for the dependence created by multiple city-year observations and any serial correlation in the error term due to persistent debt management policy.

A few other estimation details are worth noting. First, as Porter (2003) argues that odd polynomial orders have better econometric properties, and the preferred order of the polynomial regression is still open to debate in the RD literature, I present results with both linear and cubic vote share polynomials. Second, I code the timing of the change in city treasurer selection method as occurring two years after the referendum, as the referendum to change the city treasurer selection method takes effect after the incumbent elected treasurer completes their two year term.

It is important to be clear on how my main outcome of interest, the average interest rate paid on the stock of city debt after the referendum, measures city debt management policy choices. Because debt restructuring policies affect the interest rate on the stock of city debt and the debt issuance policies affect the interest rate on the flow of city debt, the dynamics of the effect of treasurer selection methods on the average interest rate depends on which policy choice is primarily affected. As I have relatively few years of data after a number of the referendums my analysis likely captures the short run effect of a change in treasurer selection methods. This

\footnotetext{
${ }^{12}$ There are four cities that put multiple referendums to the voters, two of which fail the first time and subsequently pass, in the sample period.
} 
short run effect may well differ from a longer-run effect depending on which policy choice changes with treasurer selection method. Debt restructuring policies are likely to result in a larger short than long run effect, as an effective treasurer who inherits a stock of expensive debt from less effective treasurer could reduce average interest rates quite quickly by refinancing the debt. In contrast, as the average debt issue matures over 20 years after the debt is issued, and new debt is typically issued every other year, the effect of a change of debt issuance policy may only have a small effect on the average interest rate on the stock of city debt in the short run. In any case, changes in the average interest rate on the stock of city debt are informative about the short run effect of treasurer selection methods on debt management policies.

\subsection{Treasurer Appointive Referendums}

Historically, all general law cities in California began with elected treasurers. The State Code allows for a general law city to make the treasurer position appointive if city residents vote for this change, and many cities have done so. Referendums for the appointment of city treasurers are placed on the ballot by city councils in accord with procedures outlined in the California State Code. ${ }^{13}$ The exact text of the measure is given in the California State code as, "Shall the office of city treasurer be appointive?", with the words "yes" and "no" following the question. If greater than $50 \%$ of the voters choose "yes" the referendum is carried. If the referendum is carried, the elected position is filled with a candidate of the city council's choosing on the expiration of the current treasurer's term.

I list the treasurer referendums in Table A1. ${ }^{14}$ During my sample period there are 36 appointive treasurer referendums, occurring in over $20 \%$ of the general law cities in California. Ten of the appointive treasurer referendums pass. Many referendums fail, likely because many

\footnotetext{
${ }^{13}$ Local ballot measures mostly concern local issues of land use, governance, and safety (Gordon, 2004). As Gordon (2004) notes, the California local Initiative and Referendum process was enacted in 1911 in response to the perceived influence of special interests, in particular the railroads. Currently the initiative process is available in all of California's 475 cities. All general law cities follow the procedures outlined in the state code for an initiative to become eligible for the ballot. While charter law cities have the option of having their own specific set of requirements that do not directly contravene the state code, most follow the set of requirements outlined in the state code. About $17 \%$ of local initiatives cover local government structure and organization. The local initiative process is more common in large, growing and economically diverse cities with larger public sectors; however, local income and other local political institutions play little role. Local initiatives can appear on the ballot in state and local (concurrent) or local-only (non-concurrent) elections. For an overview of the local initiative process in cities throughout the United States, see Matsusaka (2003).

${ }^{14}$ I discuss details of the exact data source and sample selection below in the data section.
} 
Americans view bureaucrats negatively, as Wilson (1989) and others have noted. The distribution of the vote shares is plotted in Figure 1. This distribution indicates that many of the referendums are quite close to the passing threshold, which is particularly useful for my RD estimation strategy to be compelling.

Whether a referendum that would be very close to passing does, indeed, barely pass (or conversely, barely fail), is unlikely to be driven by changes in the performance of the local economy, fiscal policy, other city institutions, or pressure from interest groups. Referendums may pass or fail for a variety of reasons. The work of Bowler and Donovan (1998), Gerber (1999), and Nicholson (2005) has shown that many features of ballot measures unrelated to the actual policy issue being voted on can affect their passage. For example, the salience of an issue on the national or state agenda, or cues in the question text, can determine the passage of a ballot measure. Marginal referendums may pass or fail depending on the public's view of bureaucrats at the time of the election, how other issues in the election crowd-in or crowd-out attention to the measure, the views of the swing voters who turn out to vote, etc. Exogenous shocks to who turns out to vote (perhaps due to weather conditions), or media coverage of national political or bureaucratic corruption scandals, could easily tip the balance.

\section{Data}

The empirical analysis in this paper studies the effect of treasurer appointve referendum passage on borrowing costs. In general, data on vote shares and the question text for local referendums are not compiled by state agencies. Fortunately, the newly available California Elections Data Archive (CEDA) database compiled by the Center for California Studies in cooperation with the California Secretary of State contains the key information required for this study. This database contains information on the date, content, and vote outcomes for all local initiatives and referendums appearing on the ballot in California cities from 1995 until 2006. ${ }^{15}$ I obtain my measure of whether an appointive city treasurer referendum passes and the vote share from this source.

I match the referendum data to data on city borrowing costs obtained from the City Financial Transactions Report (CFTR) data for fiscal years 1992 to 2008 for each city. The CFTR

\footnotetext{
${ }^{15}$ As the treasurer selection methods change two years after the referendum is voted on I am unable to use any of the post 2006 referendums.
} 
data comprise a uniquely detailed database with extensive coverage of many financial variables collected annually by the California State Controller for each city. All of the current 475 cities in California are required to file a report. More than $99 \%$ of cities file a financial transactions report in any given year. ${ }^{16}$ I use variables on total interest expenditure, total debt outstanding, total expenditures, and total local source revenues, all from the CFTR data. I construct my measure of city borrowing costs, the average interest rate paid on the stock of city debt, by dividing total interest expenditure by total debt outstanding. Importantly, this interest rate measures the borrowing costs that cities actually pay, including both the gross margin financial intermediaries charge, as well as, payments to investors. To match both data sources together I code the passage of a referendum based on the fiscal year as defined in the CFTR data. ${ }^{17}$

Together the data from CFTR and CEDA form the panel of California cities that I use in my central analysis. I match in data from two further sources. First, I match in data from the 1990 Decennial Census to measure population, demographic, and economic characteristics of each city. Second, I match in data from the 1992 Census of Governments on city government organization. I use this dataset to measure the baseline method of selection of the city treasurer position.

For the last section of the paper I also use data on individual debt issues matched to cities from the CFTR data in 2008. This data includes the interest payments, outstanding balance, type of debt, and term for each issue. I am only able to analyze the issue data for the 2008 cross-section as data from earlier years contain many missing values for the interest expenses. ${ }^{18}$

I construct my analysis sample in the following way. I first use California cities that appear in the 1992 Census of Governments as my base population of cities, which is 456 cities. The few cities that incorporate after 1992 are not in the sample. I also drop charter cities, as the referendum process and question as specified applies only to general law cities, and charter cities are free to redefine the duties and role for the city treasurer. ${ }^{19}$ This gives a sample of 361 cities. I then match these data to 1990 Decennial Census, CFTR, and CEDA data by city. I drop the

\footnotetext{
${ }^{16}$ Government Code section 12463 directs the California State Controller to annually compile and report to the public the financial transactions of all California cities.

${ }^{17}$ The city fiscal year runs from July to July, so for example I code referendums occurring between July of 1995 and the end of June 1996 as occurring in the 1996 fiscal year. I use the 1996 fiscal year as the first year of the sample as I do not have referendum data for the entire 1995 fiscal year.

${ }^{18}$ Interest expenses are missing for over 65 percent of the pre-2008 issue observations, but only 5 percent for the 2008 issue observations.

${ }^{19}$ General law cities follow the local government procedures and policies in the California State Code, whereas charter cities may adopt any policies and procedures which do not directly contradict state law.
} 
cities without positive reported interest costs in each year, as a number of smaller cites do not have outstanding debt in every year. I also drop the few observations with an interest rate of greater than $25 \%$; as observed interest rates on debt issues are never above $18 \%$ these are likely due to coding errors. My final sample analysis sample contains 203 cities for my full sample of cities, with the 36 treasurer appointive referendums taking place in 31 referendum cities for the referendum sample.

Table 1 presents descriptive statistics for all of the cities in my sample. Columns (1) and (2) show the means and standard deviations computed over all city-year observations dividing cities by treasurer method of selection. ${ }^{20}$ The comparison yields a number of interesting results. First, cities with elected treasurers pay higher borrowing costs. The borrowing costs in cities with elected treasurers more than $15 \%$ greater than those in cities with appointed treasurers. Cities that have elected and appointed treasurers are also quite different in other ways. Cities with elected treasurers tend to have more debt, and are more likely to have directly elected mayors and clerks. Cities with elected treasurers also have lower levels of income per capita, and a less educated population. Many of these differences are likely to make cities with elected treasurers subject to more default risk, leading to higher borrowing costs for elected treasurer cities regardless of treasurer method of selection. Thus, the descriptive statistics indicate that cities with appointed treasurers pay lower borrowing costs, but differ on key observable measures which are likely to affect borrowing costs independently of treasurers' method of selection.

As my main analysis focuses on the referendum cities sample that have elected treasurers in 1992 and subsequently vote on a treasurer appointive referendum a natural question to ask is whether it is representative of cities with elected treasurers. I present descriptive statistics comparing cities with an elected treasurer in 1992 that do and do not subsequently vote on a referendum in Table A2. By and large the cities are very similar, though the cities that vote on a referendum have somewhat lower levels of economic activity.

\footnotetext{
${ }^{20}$ Treasurer method of selection in a given year is defined from the baseline method of selection variable and any subsequent passing treasurer appointive referendums.
} 


\section{Results}

\subsection{Main Results}

Column (1) of Table 2 presents the baseline OLS estimates of $\delta$ from fitting equation (1). This estimate indicates a negative relationship between having an appointed city treasurer and borrowing costs. Conditional on city government and economic characteristics, an appointed city treasurer is associated with a reduction in borrowing costs of $13 \%$ of the baseline. As there are significant concerns about whether cross-sectional differences in, or even changes in, city treasurer method of selection are independent of unobserved determinants of borrowing costs, I next present estimates using the variation in city treasurer method of selection due to narrowly passing referendums.

In columns (2) and (3) of Table 2, I present the estimates of $\delta$ from fitting two versions of equation (3). In column (2) I present the RD estimates with a linear polynomial in vote share. This estimate indicates that appointed city treasurers do indeed cause city borrowing costs to be lower. The effect appears to be both statistically and economically significant. The passage of an appointive treasurer referendum reduces borrowing costs by $19 \%$ of baseline. The effect is also economically large. As interest payments in cities with elected treasurers account for nearly $\$ 43$ per capita, appointive treasurers reduce interest expenditure by more than $\$ 8$ per capita or $\$ 250,000$ for the city in total. Thus, the results imply that if all 137 cities with elected treasurers in the baseline period were to switch to appointed city treasurers total borrowing expenditures would fall by over $\$ 30$ million.

The baseline RD results in column (2) of Table 2 are depicted visually in Figure 3. The graph clearly shows the positive vote share-interest rate gradient, and the discontinuous drop in interest rates that occurs at the referendum passage threshold. ${ }^{21}$

While the linear vote share specification seems to capture the distribution of borrowing costs fairly well, one might still be concerned that non-linearities in the interest rate-vote share relationship might be driving the result in column (2) of Table 2. To address this potential concern I also estimate RD models with the more flexible cubic vote share polynomial. I present

\footnotetext{
${ }^{21}$ In Figure 3 I plot the raw data of the interest rates observations and the RD linear model without any controls for transparency. The comparable regression results for the linear RD model without the 1990 census controls are very similar to those in Table 2 . The coefficient on the pass dummy is -0.89 , with a city-clustered standard error of 0.34 .
} 
the results of the cubic polynomial RD model in column (3) of Table 2. The estimated effect is slightly larger than in column (2) translating into an effect of $23 \%$ of baseline, but remains statistically significantly different from zero at the $5 \%$ level.

The fact the RD estimates imply that borrowing costs are more responsive to treasurer method of selection then the OLS estimates could indicate that cities with higher levels of unobservable default risk are more likely to have appointed treasurers. Another possibility is that unobserved default risk has little relationship with treasurer method of selection, but the short run effect of an appointive city treasurer is larger than the effects in the longer run. The short run effect of switching treasurer appointive methods may be larger than the long run effect if elected treasurers fail to take advantage refinancing opportunities so that the scope for refinancing to affect borrowing costs on average is especially large in the short run.

\subsection{Robustness Tests}

Identification of the effects of institutions is challenging because any factor that affects both the cost of borrowing and institutional reform in a city may induce spurious correlation. For example, one might be concerned that cities with particularly ineffective elected treasurers implement policies that lead to a city paying higher borrowing costs. If having an ineffective elected treasurer leads citizens to narrowly pass an appointive treasurer referendum, we will estimate a negative effect where none exists. In this context, however, I believe that this issue is unlikely to be a serious problem. First, the passage of the referendum by a small margin is unlikely to be affected by significant differences in the effectiveness of a given treasurer, city fiscal policy, or other institutional characteristics. More importantly the central identification assumption is based on the smoothness of other confounding factors at the referendum passage threshold. Mean differences between cities that do and do not pass a referendum in their economic fundamentals, government, and other institutions do not contribute to identification. One might still be concerned that the narrow passage of an appointive treasurer referendum may be related to discontinuous changes in other key confounding variables. I next estimate a number of models to address this potential concern.

City Policy Outcomes Prior to Referendum Voting One advantage of having panel data on city policy outcomes is that I can test for a discontinuous jump in city borrowing costs and other policy outcomes at the referendum passage threshold before the referendum 
is actually voted on. If the narrow passage of a city treasurer referendum simply reflects a discontinuity in unobservable determinants of city borrowing costs my identification strategy could be threatened.

In Table 3 I estimate versions of equation (3) using only pre-referendum data on city financial outcomes. In the first panel of Table 3 I present the results for borrowing costs prior to the referendum vote. The results indicate that no statistically significant discontinuity exists in borrowing costs at the threshold of passage of the appointive referendum prior to the vote. The relationship between prior interest rates and future referendum vote share and passage is shown graphically in Figure 4. The figure shows clearly the lack of a significant discontinuity in interest rates prior to voting on the referendum. ${ }^{22}$ The fact that there is little evidence of a significant discontinuity in the main outcome prior to the referendum lends credence to the identification assumption.

I next examine whether there is any evidence for a discontinuity in city fiscal policy outcomes before the referendum is voted on in Panels B to D in Table 3. In general, the results of these regressions show little statistically significant relationship between pre-referendum fiscal policy outcomes and future referendum outcomes. Moreover, even the sign of the point estimates are highly sensitive to the order of the vote share polynomial. The one exception is that the coefficient on future referendum passage on Total Local Source Revenue is statistically significant at the $10 \%$ level with a linear polynomial in vote share. However, this discontinuity is highly non-robust, as the estimate switches sign and is no longer statistically significant when higher order polynomial terms are included. The results of this exercise suggest there is little reason to be concerned the main results above are driven by pre-existing non-linearities in city debt management or fiscal policy. ${ }^{23}$

Other City Institutional Changes The next threat to identification I consider is that the narrow passage of a treasurer referendum is tied to other institutional changes or reforms that might affect a city's cost of borrowing. As noted by Acemoglu and Robinson (2005), institutional

\footnotetext{
${ }^{22}$ The visual depiction of the data in Figure 3 does demonstrates that some extreme outlier interest rate observations do exist. In an unreported analysis I have also estimated the models in Table 3, Panel A excluding interest rates great than $8 \%$. The coefficient and standard error on the pass dummy from this analysis are nearly identical to those reported in Table 3.

${ }^{23} \mathrm{I}$ also show in Table A3 that there is little evidence for a discontinuity in the control variables in the $X_{i}$ matrix from the 1990 census at the referendum passage threshold. As less than $10 \%$ of the coefficients are statistically significant at the $10 \%$ significance level the results reflect what we would expect from pure chance.
} 
changes are often bundled together. As a city council decides whether to place an appointive treasurer referendum before voters, this decision may be correlated with changes other institutions that might also affect the costs of borrowing such as city budgetary institutions. An example of this would be the adoption of balanced-budget rules. In this case, the estimated treasured appointive effect may simply reflect other correlated changes in city government budgetary institutions, rather than changes in the method of selection of the city treasurer.

To shed light on this issue I examine whether the narrow passage of an appointive clerk referendum has a similar effect to narrow passage of the treasurer appointive referendum. This specification is informative for two reasons. First, as shown in Table 2 cities with elected treasurers are far more likely to have elected clerks. This fact suggests that unobservable factors that lead to the adoption of an appointive treasurer institution may also lead to the adoption of an appointive clerk institution. Indeed, many cities place appointment referendums for city clerk and city treasurer positions on the ballot simultaneously and even structure the referendum as vote to make both positions appointive. Second, as city clerks have little to do with debt management policies we would expect to see little change in borrowing costs if the treasurer appointive effect actually reflects differences in debt management policy choices by city treasurers. For these reasons clerk appointive referendum make a compelling test of whether other unobserved institutional changes are responsible for the main results.

I present the results of the appointed clerk models in Table 4. I first estimate a model similar to (1) by OLS where the appointed treasurer dummy variable is replaced by the appointed clerk variable. I then estimate an RD model similar to (3) where the referendum pass and vote share variables are from the appointive clerk referendum rather than the appointive treasurer referendum. The sample for the RD models includes all post-referendum data for the 20 cities that put an appointive city clerk referendum to the voters. ${ }^{24}$

In Table 4 I present OLS and RD estimates the appointive clerk effect on borrowing costs. In the first column of the table we see that the OLS estimate of the coefficient is negative, but not statistically significant at conventional significance levels. The point estimates switches sign in the linear RD model in the second column of Table 4, but remains statistically insignificant.

\footnotetext{
${ }^{24} \mathrm{~A}$ number of cities either put a treasurer appointive referendum and a clerk appointive referendum to the voters in the same election, or put a single referendum question to the voters that would switch both positions to be appointed. To the extent that appointive clerk and treasurer referendum are voted on jointly we would expect that the passage of a treasurer or clerk referendum would have the same measured impact. However, as the list of treasurer referendums in Table A1 shows, in practice only a few of the treasurer appointive referendums are also clerk appointive referendums.
} 
In the last column of Table 4 we see that the point estimate again switches sign, and again remains statistically insignificant. The fact the point estimates are not statistically significant provides further reassurance that the city treasurer appointive effect in Table 2 is causal and is not simply due to other unobservable institutional changes.

Narrow Margin of Victory Sample The central identification assumption in my RD analysis is that borrowing costs in cities that narrowly fail to pass a referendum form a valid counterfactual for those that narrowly do pass a referendum. Thus far I have used all the referendums available to conduct my analysis and relied on the vote share polynomial to smooth other unobserved determinants of borrowing costs. While the tests for smoothness prior to the referendum support this assumption, it is natural to ask whether the appointive effect is similar in the smaller sample of referendums that barely pass and barely fail. This sample is often termed the 'RD sample' (Angrist and Pischke, 2009). I estimate my models on this RD sample next.

In Table 5 I present estimates of RD specifications for the sample of twenty referendums that either pass or fail by less than 10 percent. The first column in Table 5 shows that the passage of treasurer appointive referendum in the linear RD specification reduces the city borrowing costs. The point estimate is substantially larger than the models in Table 2. However as the baseline level of borrowing costs is also higher in the narrow margin of victory sample the implied effect is about $28 \%$ of baseline, only slightly larger than found in the full referendum sample. The fact that the effect size is similar in the RD sample to the effect in the full referendum sample in Table 2 is comforting. The second column of Table 5 presents the results of the RD specification with a cubic polynomial estimated with the narrow margin of victory sample. Again, the results reveal that treasurer appointive referendum passage leads to lower borrowing costs. The magnitude of the estimate is even larger that that in column (1) of Table 5.

\subsection{Other Policy Outcomes}

Fiscal Policy Outcomes The results thus far have indicated that appointed city treasurers implement debt management policies that result in lower borrowing costs. I next turn to the question of whether treasurer selection method also indirectly affects fiscal policy. These effects

are of interest for two reasons. First, it is interesting to know whether narrowly focused changes in political institutions have broader effects across multiple policy areas, as policymakers controlling different policy levers may respond to one another. Second, voters might hold treasurers 
accountable by observing the indirect effects of treasurer policy choices through changes in fiscal policy, rather then debt management policy per se. For this form of indirect accountability (with appropriate attribution) to be effective fiscal policy would need to respond to changes in debt management policy.

In Table 6 I present RD estimates the appointive treasurer effect for fiscal policy. In the first panel of the table I examine the appointive effect on total city expenditure. In this panel we see that the while point estimate of the coefficient is positive, it is not statistically significant at conventional significance levels in both RD specifications. That there is little evidence of an effect on total expenditure likely indicates the reduction in borrowing costs is spent on other public goods. In the second panel of Table 6 I look at the appointive effect on locally generated revenue. In the first column the estimate is positive and statistically significant at the $10 \%$ level. In the second column the point estimate is similar, but no longer statistically significant. The lack of a negative effect suggests that the reduction in borrowing costs is not passed on to taxpayers. The weak evidence of an increase in revenue could be due to an effect of appointive city treasurers on tax collection rather then fiscal policy per se. The last panel in Table 6 examines the appointive effect for the stock of total debt outstanding. Again, the results show little evidence of an appointive city treasurer effect on total debt outstanding.

Debt Issuance and Management Costs In this section I investigate whether other borrowing or administrative costs are affected by treasurer method of selection, as interest rates are not the only cost cities pay to borrow. I examine whether a city treasurers' method of selection also affects other costs directly related to the issuance of debt. Whether other costs of debt issuance respond to treasurer method of selection is important for understanding the effect of treasurer method of selection on total borrowing costs.

I consider two additional costs. I first examine whether cities with appointed treasurers spend more or less on per issue fees to private sector debt issuance consultants. The effect could plausibly go in either direction. Effective city treasurers may be able to substitute their effort and expertise for that of a consultant, reducing city expenditure on advisory services. On the other hand, effective city treasurers may be effective because they select higher quality financial advisors whose services may be more costly. It is also possible that private sector debt consultants are able to extract rents from ineffective city treasurers who are not aware of the services they really need or the price they should be willing to pay. 
In the first panel of Table 7 in columns (1) and (2), I present the results of estimating a RD model similar to equation (3) with the outcome of debt issuance consultant expenditure. The results clearly show little statistically significant effect of appointive treasurer referendum passage on expenditure on debt consultants.

Second, I also examine whether the cost of government administration in the city treasurer department increases with an appointed city treasurer. Department costs might change if the appointive city treasurers' effect is due to hiring more or better quality staff in the finance department, or spending more on the city treasurer position itself. In practice, the effect on spending from reallocating the city treasurer position from a politician to a bureaucrat may well be small. Many small cities reallocate the debt management task to the finance director in response to the ballot measure passing, and do not create additional positions.

In the first panel of Table 7 in columns (1) and (2), I present the results of estimating a RD model similar to equation (3) with the outcome of total expenditure on general government administration. The results are mixed. The linear RD estimate in column (1) indicates that appointive city treasurers do significantly increase general government administration expenditure. However, the results with a cubic polynomial in column (2) indicate that the impact of an appointive treasurer on government administration is not statistically significant. Thus, the results in Table 7 provide little consistent evidence of strong appointive city treasurer effect on the cost of government administration.

\section{Debt Restructuring or New Debt Issuance Policies?}

The results presented thus far indicate that appointed treasurers reduce city borrowing costs. What explains these findings? In this section, I utilize highly detailed issue level data from the 2008 cross-section to examine evidence on whether the appointive effect is primarily due to debt restructuring or debt issuance policies. I first examine whether appointed and elected city treasurers' choose different debt restructuring policies. I then consider whether appointed and elected treasurers choose different debt issuance policies.

Understanding the channel for the appointive effect allows us to assess whether the effect can be interpreted as reflecting public official performance. As both treasurer effort and expertise are required to restructure existing debt at a lower cost, debt restructuring is closely related 
to treasurer effort and skill inputs. It is possible that refinancing may result in some characteristics of the debt issue the residents may value changing, the fact refinancing opportunities are primarily driven by the variation in market interest rates over time that all treasurers face suggests that changes in characteristics are likely to be second order. Thus, an interpretation of borrowing cost reductions due to refinancing as public official performance seems warranted. In contrast, the central policy choice affecting the cost of borrowing for new debt is the method of sale, which seems more closely related to catering to special interest lobbying than to the inputs supplied by a city treasurer.

\subsection{Measuring Debt Restructuring and Debt Issuance Policies}

To separately measure debt restructuring and new debt issuance policies one would ideally use data on the flow of debt issues over time. Unfortunately, I only have access to a single cross section of debt-issue level data that reports interest rates reliably. The debt issue level data available as prior to the 2008 cross-section does not record an interest rate for the majority of the records. ${ }^{25}$

I am able to separately measure debt restructuring and debt issuance policies indirectly by examining how the appointive effect depends on when the debt was issued. The test is based on the idea that a city treasurers debt issuance policies can only affect the interest rates on the debt issued after they take office. Debt issuance policies will then only affect the interest rate on debt issued after the referendum. In contrast, the appointive effect on debt issued prior to the referendum must be due to the selective retiring of expensive debt through refinancing. Debt restructuring policies will then only affect the interest rate on debt issued before the referendum.

I again use my regression discontinuity approach to estimate the effect of treasurer methods of selection on debt issuance and debt restructuring policies. I estimate models of the following form for the interest rate, $I_{i j}$,

$$
I_{i j}=\operatorname{spass}_{i j}+P_{g}\left(s_{i}\right)+X_{i} \beta+\epsilon_{i j}
$$

where $i$ indexes the referendum and $j$ indexes the issue. The variable pass $i$ is a dummy variable that takes a value is a referendum passes in a prior year and value zero otherwise. $\mathrm{P}_{g}\left(\mathrm{~s}_{i}\right)$ is a polynomial function of the referenda vote share, $s_{i}$, of order $g . X_{i}$ is the same vector of

\footnotetext{
${ }^{25}$ As the debt issue data is for the fiscal year 2008 it ends on June 302008 , so the interest rates on these issues are not affected by the subsequent financial crisis in fall 2008.
} 
covariates from the 1990 census in the city where the referendum occurs as in model (1), and $\epsilon_{i t}$ is the error term. Thus, the appointive effect, $\delta$, is estimated controlling for the percent voting in favor with a flexible polynomial functional form, as usual.

\subsection{Results}

The results of estimating (4) are reported in Table 8. I first present the results for all debt issues, and then turn to estimating on the models on the samples with: (1) all pre-referendum debt issues, to measure the debt refinancing policy response and (2) all post-referendum debt issues, to measure the debt issuing policy response. I also estimate models where I control for the type term length of the debt issue in columns (2), (4) and (6). The results in columns (1) and (2) demonstrate a similar appointive effect as noted above, about $25 \%$ of the baseline interest rate, though they are less precisely estimated.

Debt Restructuring The results from estimating equation (4) for the debt issued before the referendum are presented in columns (3) and (4) of Table 8. These results indicate that differences in city treasurer methods of selection cause differences in debt restructuring policies. The coefficient estimates are quite large and statistically significantly different from zero at the $5 \%$ level. The magnitude as a percentage of baseline is substantial, representing an effect of over $40 \%$ of baseline. ${ }^{26}$

It is also important to note that the results hardly differ when debt characteristics are included as controls. This is important as attributes of a public debt issue other than the interest rate may affect resident welfare. For example, long-term debt with a fixed interest rate could be more valuable to risk averse city residents than short-term or variable interest rate debt. Thus far I have discussed borrowing costs as if lower borrowing costs are a public good, however if borrowing cost reducting are simply due to changes in other debt attributes residents dislike welfare intreprerations are difficult. The fact that the results are so similar with and without debt characteristic controls indicates that the appointive effect is not primarily due to changes in debt attributes residents may value. Thus these results suggest that lower borrowing costs from refinancing can be interpreted as welfare improving. In any case, the debt restructuring

\footnotetext{
${ }^{26}$ The baseline level of interest rates may not be the relevant counterfactual as the highest interest debt is most likely to be refinanced. The effects are still quite large compared the maximum level of interest rates in the sample, representing a response of over $20 \%$.
} 
response is substantial and provides support for a public official performance interpretation of the appointive effect.

Debt Issuance The results of estimating equation (4) for the debt issued after the referendum are presented in columns (5) and (6) of Table 8. These results provide little support for debt issuance response. The point estimates in both columns are actually positive and not statistically significantly different from zero. Thus, there is little evidence that appointed treasures choose a different debt issuance policy.

In sum, the results shed some light on how differences in policy choices between elected and appointed treasurers account for the appointive effect. Appointed treasurers are more likely to restructure expensive debt, but not issue new debt at lower cost. The fact that the primary debt management policy difference between appointed and elected treasurers is debt restructuring lends further credence to the results above. As the median term length of a debt issue in the sample is 21 years there is little scope for debt issuance policy to affect the average interest rates on the stock of city debt in the short run. In contrast, the scope for the refinancing of expensive debt to have an especially large effect on average interest rates on the stock of city debt shortly after the method of selection of the treasurer switches is far greater.

\section{Conclusion}

This paper has documented that there are substantial effects from bureaucratic control of city debt policy: assigning the debt task to a bureaucrat reduces city borrowing costs. The results indicate that appointive treasurers reduce a city's cost of borrowing by $13 \%$ to $23 \%$. The appointive effect is also economically significant. The results imply that if all cities in California with elected treasurers were to appoint them, total borrowing expenditures would be reduced by more than $\$ 20$ million per year. Thus, this paper has demonstrated that alternative political institutions do indeed cause meaningful differences in policymaking.

I also present evidence that the appointive effect is primarily due to different debt restructuring, not different debt issuance, policy choices. As both treasurer effort and expertise are required to restructure existing debt at a lower cost, the evidence for a debt restructuring channel indicates an important role for treasurer supplied inputs in explaining the findings. In addition, as the appointive effect seems to have little to do with changes in attributes of the debt issue 
interpreting the appointive effect as reflecting better public official performance seems to be warranted.

There are several implications for future research. First, it would be interesting to examine whether similar differences in policymaking are found for less technical policy choices. The theoretical arguments noted above indicate politicians likely have a comparative advantage in less technical policy areas. It would be interesting to examine empirical evidence on whether or not this is the case. Second, as highly detailed data on policy maker expertise are unavailable for city treasurers, it would be interesting to examine how differences in expertise affect policy choices and performance in a context where such measures are available.

The results of this study also have broader implications for the organization of public good provision. They suggest, for example, that the division of policymaking tasks typical in many advanced democracies, with appointed officials conducting the more-technical monetary and regulatory policy, and elected officials conducting the less-technical fiscal policy, is appropriate. Efforts to improve governance in developing countries may well be enhanced by emulating the division of policymaking tasks in advanced democracies. 


\section{$7 \quad$ References}

Acemoglu, Daron (2005) "Constitutions, Politics and Economics: A Review Essay on Persson and Tabellini's "The Economic Effects of Constitutions", "Journal of Economic Literature, 43(4): pp. $1025-1048$.

Acemoglu, Daron and James Robinson (2005) "Unbundled Institutions," Journal of Political Economy, 113(5): pp. 949-995.

Acemoglu, Daron, David Ticchi and Andrea Vindigni (2006) "Emergence and Persistence of Inefficient States," National Bureau of Economic Research, Working Paper 12748.

Aghion, Philippe, Alberto Alesina, and Francesco Trebbi (2004) "Endogenous Political Institutions," Quarterly Journal of Economics, 119(2): pp. 565-613.

Alesina, Alberto and Guido Tabellini (1990) "A Positive Theory of Fiscal Deficits and Government Debt," Review of Economic Studies, 57:pp. 403-414.

Alesina, Alberto and Guido Tabellini (2007) "Bureaucrats or Politicians? Part I: A Single Policy Task," American Economic Review, 97(1): pp. 169-79.

Alesina, Alberto and Guido Tabellini (2008) "Bureaucrats or Politicians? Part II: Multiple Policy Tasks," Journal of Public Economics, 92(3-4): pp. 426-447.

Angrist, Joshua and Jorn-Steffen Pischke (2009) Mostly Harmless Econometrics: An Empiricist's Companion, Princeton, NJ: Princeton University Press.

Besley, Timothy (2006) Principled Agents? The Political Economy of Good Government. Oxford, UK: Oxford University Press.

Besley, Timothy and Anne Case (1995) "Does Electoral Accountability Affect Economic Policy Choices? Evidence from Gubernatorial Term Limits," Quarterly Journal of Economics, 110(3): pp. 769-798

Besley, Timothy and Anne Case (2003) "Political Institutions and Policy Choices: Evidence from the United States," Journal of Economic Literature, 41(1): pp. 7-73.

Besley, Timothy and Stephen Coate (2003) "Elected versus Appointed Regulators: Theory and Evidence," Journal of the European Economics Association, 1(5): pp. 1176-1206.

Besley, Timothy and Abigail Payne (2006) "Implementation of Anti-Discrimination Policy: Does Judicial Selection Matter?," McMaster University, Working Paper.

Bowler, Shaun and Todd Donovan (1998) Demanding Choices, Ann Arbor, MI: University of Michigan Press.

California Debt Issuance and Advisory Commission (2006) California Debt Issuance Primer, Sacramento, CA: CDIAC.

California Municipal Treasurers Association (2001) City Treasurers Handbook. Sacramento, CA: CMTA. 
Cellini, Stephanie Riegg, Fernando Ferreira and Jesse Rothstein (2008) "The Value of School Facilities: Evidence from a Dynamic Regression Discontinuity Design," National Bureau of Economic Research, Working Paper 14516.

Coate, Stephen and Brian Knight (2009) "Government Form and Public Spending: Theory and Evidence from U.S. Municipalities," National Bureau of Economic Research, Working Paper 14857.

Feldstein, Sylvan and Frank Fabozzi (2008) The Handbook of Municipal Bonds, Hoboken, NJ: John Wiley and Sons.

Ferraz, Claudio and Frederico Finan (2007) "Electoral Accountability and Corruption in Local Governments: Evidence from Audit Reports." UCLA, Working paper.

Ferraz, Claudio and Frederico Finan (2008) "Exposing Corrupt Politicians: The Effect of Brazil's Publicly Released Audits on Electoral Outcomes," Quarterly Journal of Economics,123(2): 703-745.

Ferreira, Fernando and Joseph Gyourko (2009), "Do Political Parties Matter? Evidence from U.S. Cities," Quarterly Journal of Economics, 124(1): pp. 349-397.

Gerber, Elisabeth (1999) The Populist Paradox, Princeton, NJ: Princeton University Press.

Gordon, Tracy (2004) The Local Initiative in California, San Francisco, CA: Public Policy Institute of California.

Jones, Ben and Ben Olken (2005) "Do Leaders Matter? National Leadership and Growth Since World War II," Quarterly Journal of Economics, 120 (3): pp. 835 -864.

Joseph, James (1994) Debt Issuance and Management: A Guide for Smaller Governments, Chicago, IL: Government Financial Officers Association.

Lee, David (2008) "Randomized Experiments from Non-random Selection in U.S. House Elections, Journal of Econometrics, 142 (2008): pp. 675-697.

Lee, David, and Thomas Lemieux (2008) "Regression Discontinuity Designs in Economics," National Bureau of Economic Research, Working Paper 14723.

Leonard, Paul (2004) "Debt Management," in Management Policies in Local Government Finance, edited by Aaronson, Richard and Eli Schwartz, Washington, DC: ICMA.

Levitt, Arthur (2009) "Taxpayers Fleeced When Leaders Tap Muni Market," Bloomberg.com (October 21, 2009): http://www.bloomberg.com/apps/news?pid=newsarchivesid=aZo2O7uRC.Ok.

List, John and Daniel Sturm (2006) "How Elections Matter: Theory and Evidence from Environmental Policy," Quarterly Journal of Economics, 121(4): pp. 1249 - 1281.

Maskin, Eric and Jean Tirole (2004) "The Politician and the Judge: Accountability in Government," American Economic Review, 94(1): pp. 1034-1054.

Matsusaka, John (2003) "I \& R in American Cities: Basic Patterns," in Initiative and Referendum Almanac, edited by M. Dane Waters, Durham, NC: Carolina Academic Press. 
Nicholson, Steven (2005) Voting the Agenda: Candidates, Elections and Ballot Propositions, Princeton, NJ: Princeton University Press.

Persson, Torsten and Guido Tabellini (2003) The Economic Effects of Constitutions, Cambridge, MA: MIT Press.

Porter, Jack (2003) "Estimation in the Regression Discontinuity Model," University of Wisconsin, working paper.

Poterba, James (1994) "State Responses to Fiscal Crisis: The Effects of Budgetary Institutions and Politics", Journal of Political Economy, 102 (August): 799-821

Robbins, Mark and Bill Simonson (2007) "Competition and Selection in Municipal Bond Sales: Evidence from Missouri," Public Budgeting and Finance, 27(2): pp. 88-103.

Simonson, Bill, Mark Robbins and Lee Helgerson (2001) "The Influence of Jurisdiction Size and Sale Type on Municipal Bond Interest Rates: An Empirical Analysis," Public Administration Review, 61(6): pp. 709-717.

Spiotto, James (2008) "A History of Modern Municipal Defaults," in The Handbook of Municipal Bonds, edited by Feldstein, Sylvan and Frank Fabozzi, Hoboken, NJ: John Wiley and Sons.

Vlaicu, Razvan (2008) "Executive Performance under Direct and Hierarchical Accountability Structures: Theory and Evidence," University of Maryland, working paper.

Wilson, James (1989) Bureaucracy: What Government Agencies Do and Why They Do It, Jackson, TN: Basic Books. 
TABLE 1: Descriptive Statistics, by City Treasurer Appointive Status

\begin{tabular}{|c|c|c|c|}
\hline & $\begin{array}{c}\text { Treasurer Position } \\
\text { Appointed } \\
\text { (1) }\end{array}$ & $\begin{array}{l}\text { Treasurer Position } \\
\text { Elected } \\
\text { (2) }\end{array}$ & $\begin{array}{c}\text { (1)-(2) } \\
\text { t-stat } \\
\text { [p-value] } \\
\text { (3) }\end{array}$ \\
\hline \multicolumn{4}{|l|}{ (1) Outcome: } \\
\hline Interest Rate Paid on Total Outstanding Debt (\%) & $\begin{array}{c}2.17 \\
(1.85)\end{array}$ & $\begin{array}{c}2.57 \\
(1.93)\end{array}$ & $\begin{array}{c}-3.03 \\
{[0.003]}\end{array}$ \\
\hline \multicolumn{4}{|l|}{ (2) City Finances (2000 \$): } \\
\hline Total Local Source Revenue per capita & $\begin{array}{c}637 \\
(1225)\end{array}$ & $\begin{array}{c}646 \\
(1075)\end{array}$ & $\begin{array}{c}-0.07 \\
{[0.944]}\end{array}$ \\
\hline Total Expenditure per capita & $\begin{array}{c}1317 \\
(1789)\end{array}$ & $\begin{array}{c}1561 \\
(2557)\end{array}$ & $\begin{array}{c}-1.10 \\
{[0.273]}\end{array}$ \\
\hline Total Debt Outstanding per capita & $\begin{array}{c}1178 \\
(1813)\end{array}$ & $\begin{array}{c}1691 \\
(3189)\end{array}$ & $\begin{array}{c}-2.01 \\
{[0.046]}\end{array}$ \\
\hline \multicolumn{4}{|l|}{ (3) City Government Characteristics: } \\
\hline Mayor-Council Form of Government & $\begin{array}{c}0.09 \\
(0.29)\end{array}$ & $\begin{array}{c}0.21 \\
(0.41)\end{array}$ & $\begin{array}{c}-2.72 \\
{[0.007]}\end{array}$ \\
\hline Appointed City Clerk & $\begin{array}{c}0.91 \\
(0.29)\end{array}$ & $\begin{array}{c}0.12 \\
(0.33)\end{array}$ & $\begin{array}{c}21.88 \\
{[0.000]}\end{array}$ \\
\hline Fraction with Full-Time Elected Officials & $\begin{array}{c}0.03 \\
(0.18)\end{array}$ & $\begin{array}{c}0.01 \\
(0.08)\end{array}$ & $\begin{array}{c}1.63 \\
{[0.104]}\end{array}$ \\
\hline \multicolumn{4}{|l|}{ (4) City Economic Characteristics: } \\
\hline City Population & $\begin{array}{c}34416 \\
(38509)\end{array}$ & $\begin{array}{c}31104 \\
(32416)\end{array}$ & $\begin{array}{c}0.75 \\
{[0.453]}\end{array}$ \\
\hline Per Capita Income (1990 \$) & $\begin{array}{c}17521 \\
(10133)\end{array}$ & $\begin{array}{l}14519 \\
(6835)\end{array}$ & $\begin{array}{c}2.98 \\
{[0.003]}\end{array}$ \\
\hline Fraction College Graduate & $\begin{array}{c}0.23 \\
(0.17)\end{array}$ & $\begin{array}{c}0.17 \\
(0.11)\end{array}$ & $\begin{array}{c}3.67 \\
{[0.000]}\end{array}$ \\
\hline Employment-Population Ratio & $\begin{array}{c}0.46 \\
(0.09)\end{array}$ & $\begin{array}{c}0.44 \\
(0.08)\end{array}$ & $\begin{array}{c}1.85 \\
{[0.065]}\end{array}$ \\
\hline Number of Observations & 2228 & 1894 & \\
\hline
\end{tabular}

Notes: Source: Author's calculations using data from California CFTR, and CEDA data from 1992 to 2008, 1990 Decennial Census, and 1992 Census of 
Government data. The unit of observation is city-year. The main entries in column (1) present the mean of the selected variables for cities with appointed treasurers. The main entries in column (2) present the mean of the selected variables for cities with elected treasurers. The standard deviations of the selected variable are presented in parenthesis in columns (1) and (2). The main entries in column (3) present the test statistics for a test of differences in means between column (1) and (2), with the p-value of the test presented in square brackets. The sample includes all general law cites in California with a municipal government in the 1992 Census of Governments and positive interest expenses in each year. All monetary values are expressed in 2000 \$nless noted otherwise. The

variables Interest Rate Paid on Total Outstanding Debt, Total Local Source Revenue per capita, Total Expenditure per capita, and Total Debt Outstanding per capita are based on data from the California City Financial Transactions Reports (CFTR). The variables Mayor-Council Form of Government, Appointed City Treasurer, Appointed City Clerk, and Full-Time Elected Officials are based on data from the 1992 Census of Governments. The variable City Population is based on data from the California E-1 Population Tables. The variables Per Capita Income, Fraction College Graduate, and Employment-Population Ratio are based on data from the 1990 Decennial Census. Definition of the variables: Interest Rate Paid on Total Outstanding Debt (\%) is the ratio of total interest expenses divided by total debt outstanding; Total Expenditure is the total expenditure to deliver city services; Total Local Source Revenue is total city revenue net of transfers from the Federal, State, and County governments; Total Debt Outstanding is the total stock of debt outstanding issued by the city; Mayor-Council Form of Government indicates whether or not the city has a directly elected mayor; Full-Time Elected Officials indicates whether or not the elected officials serve in a full-time capacity; City Population is the city population annually estimated by the California state Department of Finance; Per Capita Income is the per capita income in the city; Fraction College Graduate is the fraction of the population with a college degree in the city; and Employment-Population Ratio is the ratio of employment to population in the city. 
TABLE 2: The Effect of Appointive City Treasurers on City Borrowing Costs

Dependent Variable $=$ Interest Rate on Total Outstanding Debt

Model $=\quad$ OLS $\quad$ RD linear $\quad$ RD cubic

(1) (2) (3)

Treasurer Appointed $\quad-0.34^{* *}$

Treasurer Appointive Referendum Pass

Treasurer Appointive Referendum Pass

$\begin{array}{cc}-0.68 * * & -0.81 * * \\ (0.31) & (0.38)\end{array}$

Number of Observations

1990 Census controls

Baseline Dependent Variable Mean

[Standard Deviation]

$\begin{array}{ccc}4122 & 254 & 254 \\ \text { Yes } & \text { Yes } & \text { Yes } \\ 2.64 & 3.52 & 3.52 \\ {[2.43]} & {[2.11]} & {[2.11]}\end{array}$

Sample

All Cities

Referendum Cities

Notes: Source: Author's calculations using data from California City Financial Transactions Reports, and CEDA data from 1992 to 2008, 1992 Census of Government data and 1990 Decennial Census data. The sample in column (1) includes all general law cites in California with a municipal government in the 1992 Census of Governments and positive interest expenses in each year. The sample in column (2) and (3) includes all general law cites in California with a municipal government in the 1992 Census of Governments, positive interest expenses in each year, and an appointive treasurer referendum put to voters in a prior year. The variable Treasurer Appointed takes a value of one if the treasurer is appointed in city $i$ in year $t$. The variable Treasurer Appointive Referendum Pass takes a value of one if a local treasurer appointive referendum passed in a prior year in city $i$ in year $t$. The unit of observation is referndum-year. Each column presents the results from one regression specification. The main entries are coefficient estimates. The entries in parentheses are standard errors clustered at the city level. All models include city characteristics from the 1990 Census: Population Size, Percentage White, Percentage Black, Percentage Less Than Seventeen, Percentage Greater Than Sixty-Five, Percentage College Graduate, Percentage High School Graduate, Mayor-Council Form of Government, and Employment-Population Ratio. The models in columns (2) and (3) also control for a linear and cubic polynomial in vote share respectively. * indicates significantly different from zero at the $10 \%$ level of significance; ** indicates significantly different from zero at the $5 \%$ level of significance; *** indicates significantly different from zero at $1 \%$ level of significance. 
TABLE 3: City Financial Outcomes Prior to Treasurer Appointive Measure Vote

Model $=\quad$ RD linear $\quad$ RD cubic

A. Dependent Variable $=$ Interest Rate on Total Outstanding Debt

Future Treasurer Appointive Referendum Pass $\quad-0.59$

Number of Observations

327

327

1990 Census Controls

Yes

Yes

Baseline Dependent Variable Mean

3.52

3.52

[Standard Deviation]

[2.11]

[2.11]

B. Dependent Variable $=$ Real Total Expenditure per capita

Future Treasurer Appointive Referendum Pass

2.58

(161.21)

Number of Observations

1990 Census Controls

Baseline Dependent Variable Mean

[Standard Deviation]

$\begin{array}{cc}327 & 327 \\ \text { Yes } & \text { Yes } \\ 868.86 & 868.86 \\ {[346.87]} & {[346.87]}\end{array}$

$(235.03)$

$40.76^{*}$
$(20.18)$

327

Yes Yes

1990 Census Controls

368.53

[116.52]

368.53

[116.52]

[Standard Deviation]

$$
\text { [116.52] }
$$

D. Dependent Variable $=$ Real Total Outstanding Debt per capita

Future Treasurer Appointive Referendum Pass

$-86.67$

(380.79)

$-400.94$

(519.76)

Number of Observations

$327 \quad 327$

1990 Census Controls

Yes

855.76

Yes

Baseline Dependent Variable Mean

[743.56]

855.76

[743.56]

Sample

Referendum Cities

Notes: Source: Author's calculations using data from California City Financial Transactions Reports, and CEDA data from 1992 to 2008, 1992 Census of Government data and 1990 Decennial Census data. The sample includes all general law cites in California with a municipal government in the 1992 Census of Governments, positive interest expenses in each year, and an appointive treasurer referendum put to voters 
in a future year. The variable Future Treasurer Appointive Referendum Pass takes a value of one if a local treasurer appointive referendum passed in a future year in city $i$ in year $t$. The unit of observation is referendum-year. Each column presents the results from one regression specification. The main entries are coefficient estimates. The entries in parentheses are standard errors clustered at the city level. All models include city characteristics from the 1990 Census: Population Size, Percentage White, Percentage Black, Percentage Less Than Seventeen, Percentage Greater Than Sixty-Five, Percentage College Graduate, Percentage High School Graduate, Mayor-Council Form of Government, and Employment-Population Ratio. The models in columns (1) and (2) also control for a linear and cubic polynomial in vote share respectively. * indicates significantly different from zero at the $10 \%$ level of significance; ** indicates significantly different from zero at the $5 \%$ level of significance; $* * *$ indicates significantly different from zero at $1 \%$ level of significance. 
TABLE 4: The Effect of Appointive City Clerks on City Borrowing Costs

Dependent Variable $=$ Interest Rate on Total Outstanding Debt

$\begin{array}{cccc}\text { Model }= & \text { OLS } & \text { RD linear } & \text { RD cubic } \\ (1) & (2) & (3)\end{array}$

Clerk Appointed $\quad-0.12$

Clerk Appointive Ballot Pass

$(0.13)$

0.78

(0.55)

$-0.93$

Number of Observations

4122

155

155

1990 Census controls

Yes

Yes

Yes

Baseline Dependent Variable Mean

2.64

3.43

3.43

[Standard Deviation]

[2.43]

[2.15]

[2.15]

Sample

All Cities

Referendum Cities

Notes: Source: Author's calculations using data from California City Financial Transactions Reports, and CEDA data from 1992 to 2008, 1992 Census of Government data and 1990 Decennial Census data. The sample in column (1) includes all general law cites in California with a municipal government in the 1992 Census of Governments and positive interest expenses in each year. The sample in column (2) and (3) includes all general law cites in California with a municipal government in the 1992 Census of

Governments, positive interest expenses in each year, and an appointive clerk referendum put to voters in a prior year. The variable Clerk Appointed takes a value of one if the clerk is appointed in city $i$ in year $t$. The variable Clerk Appointive Referendum Pass takes a value of one if a local clerk appointive referendum passed in a prior year in city $i$ in year $t$. The unit of observation is referendum-year. Each column presents the results from one regression specification. The main entries are coefficient estimates. The entries in parentheses are standard errors clustered at the city level. All models include city characteristics from the 1990 Census: Population Size, Percentage White, Percentage Black, Percentage Less Than Seventeen, Percentage Greater Than Sixty-Five, Percentage College Graduate, Percentage High School Graduate, Mayor-Council Form of Government, and Employment-Population Ratio. The models in columns (2) and (3) also control for a linear and cubic polynomial in vote share respectively. * indicates significantly different from zero at the $10 \%$ level of significance; ** indicates significantly different from zero at the $5 \%$ level of significance; *** indicates significantly different from zero at $1 \%$ level of significance. 
TABLE 5: The Effect of Appointive City Treasurers on City Borrowing Costs: Narrow Margin of Victory Sample

Dependent Variable $=$ Interest Rate on Total Outstanding Debt

\begin{tabular}{lcc}
\hline & Model $=$ & RD linear \\
& $(1)$ & $\begin{array}{c}\text { RD cubic } \\
(2)\end{array}$ \\
\hline Treasurer Appointive Referendum Pass & $-1.13^{* * *}$ & $-2.02^{* * *}$ \\
& $(0.23)$ & $(0.53)$ \\
Number of Observations & 160 & 160 \\
1990 Census Controls & Yes & Yes \\
Baseline Dependent Variable Mean & 4.01 & 4.01 \\
[Standard Deviation] & {$[1.76]$} & {$[1.76]$} \\
& \multicolumn{2}{c}{ Referendum Cities, } \\
Sample & Margin of Victory $>-0.1 \&<0.1$ \\
\hline
\end{tabular}

Notes: Source: Author's calculations using data from California City Financial Transactions Reports, and CEDA data from 1992 to 2008, 1992 Census of Government data and 1990 Decennial Census data. The sample includes all general law cites in California with a municipal government in the 1992 Census of Governments, positive interest expenses in each year, and an appointive treasurer referendum put to voters in a prior year with a vote share of between 0.4 and 0.6. The variable Treasurer Appointive Referendum Pass takes a value of one if a local treasurer appointive referendum passed in a prior year in city $i$ in year $t$. The unit of observation is referendum-year. Each column presents the results from one regression specification. The main entries are coefficient estimates. The entries in parentheses are standard errors clustered at the city level. All models include city characteristics from the 1990 Census: Population Size, Percentage White, Percentage Black, Percentage Less Than Seventeen, Percentage Greater Than SixtyFive, Percentage College Graduate, Percentage High School Graduate, Mayor-Council Form of Government, and Employment-Population Ratio. The models in columns (1) and (2) also control for a linear and cubic polynomial in vote share respectively. * indicates significantly different from zero at the $10 \%$ level of significance; ** indicates significantly different from zero at the $5 \%$ level of significance; *** indicates significantly different from zero at $1 \%$ level of significance. 
TABLE 6: The Effect of Appointive City Treasurers on City Fiscal Policy Outcomes

\begin{tabular}{|c|c|c|}
\hline Model $=$ & $\begin{array}{l}\text { RD linear } \\
\text { (1) }\end{array}$ & $\begin{array}{c}\text { RD cubic } \\
(2)\end{array}$ \\
\hline \multicolumn{3}{|l|}{ A. Dependent Variable = Real Total Expenditure per capita } \\
\hline Treasurer Appointive Referendum Pass & $\begin{array}{c}140.79 \\
(227.64)\end{array}$ & $\begin{array}{c}166.04 \\
(270.29)\end{array}$ \\
\hline $\begin{array}{l}\text { Number of Observations } \\
1990 \text { Census Controls } \\
\text { Baseline Dependent Variable Mean } \\
\text { [Standard Deviation] }\end{array}$ & $\begin{array}{c}254 \\
\text { Yes } \\
868.86 \\
{[346.87]}\end{array}$ & $\begin{array}{c}254 \\
\text { Yes } \\
868.86 \\
{[346.87]}\end{array}$ \\
\hline \multicolumn{3}{|c|}{ B. Dependent Variable = Real Total Local Source Revenue per capita } \\
\hline Treasurer Appointive Referendum Pass & $\begin{array}{l}108.57^{*} \\
(60.00)\end{array}$ & $\begin{array}{c}86.19 \\
(74.02)\end{array}$ \\
\hline $\begin{array}{l}\text { Number of Observations } \\
1990 \text { Census Controls } \\
\text { Baseline Dependent Variable Mean } \\
\text { [Standard Deviation] }\end{array}$ & $\begin{array}{c}254 \\
\text { Yes } \\
368.53 \\
{[116.52]}\end{array}$ & $\begin{array}{c}254 \\
\text { Yes } \\
368.53 \\
{[116.52]}\end{array}$ \\
\hline \multicolumn{3}{|c|}{ C. Dependent Variable $=$ Real Total Outstanding Debt per capita } \\
\hline Treasurer Appointive Referendum Pass & $\begin{array}{l}-139.17 \\
(542.71)\end{array}$ & $\begin{array}{c}-23.48 \\
(624.41)\end{array}$ \\
\hline $\begin{array}{l}\text { Number of Observations } \\
1990 \text { Census Controls } \\
\text { Baseline Dependent Variable Mean } \\
\text { [Standard Deviation] }\end{array}$ & $\begin{array}{c}254 \\
\text { Yes } \\
855.76 \\
{[743.56]}\end{array}$ & $\begin{array}{c}254 \\
\text { Yes } \\
855.76 \\
{[743.56]}\end{array}$ \\
\hline Sample & \multicolumn{2}{|c|}{ Referendum Cities } \\
\hline
\end{tabular}

Notes: Source: Author's calculations using data from California City Financial Transactions Reports, and CEDA data from 1992 to 2008, 1992 Census of Government data and 1990 Decennial Census data. The sample includes all general law cites in California with a municipal government in the 1992 Census of Governments, positive interest expenses in each year, and an appointive treasurer referendum put to voters in a future year. The variable Treasurer Appointive Referendum Pass takes a value of one if a local treasurer appointive referendum passed in a prior year in city $i$ in year $t$. The unit of observation is referendum-year. Each column presents the results from one regression specification. The main entries are coefficient estimates. The entries in parentheses are standard errors clustered at the city level. All models include city characteristics from the 1990 Census: Population Size, Percentage White, Percentage Black, Percentage Less Than Seventeen, Percentage Greater Than Sixty-Five, Percentage College Graduate, Percentage High School Graduate, Mayor-Council Form of Government, and Employment-Population Ratio. The models in columns (1) and (2) also control for a linear and cubic polynomial in vote share respectively.* indicates significantly different from zero at the $10 \%$ level of significance; ** indicates significantly different from zero at the $5 \%$ level of significance; $* * *$ indicates significantly different from zero at $1 \%$ level of significance. 
TABLE 7: The Effect of Appointive City Treasurers on Other City Borrowing Costs

Model $=\quad$ RD linear $\quad$ RD cubic

(1)

(2)

A. Dependent Variable $=$ Expenditure on Debt Consultants per capita

Treasurer Appointive Referendum Pass

$-17.41$

(40.48)

$-48.96$

Number of Observations

254

254

1990 Census Controls

Yes

Yes

Baseline Dependent Variable Mean

28.00

28.00

[Standard Deviation]

[71.43]

\section{B. Dependent Variable $=$ Expenditure on Management and Support Department per capita}

Treasurer Appointive Referendum Pass

$65.56^{* *}$

(25.17)

Number of Observations

1990 Census Controls

Baseline Dependent Variable Mean

[Standard Deviation]

$\begin{array}{cc}254 & 254 \\ \text { Yes } & \text { Yes } \\ 63.47 & 63.47 \\ {[44.58]} & {[44.58]}\end{array}$

Referendum Cities
47.42

254

63.47

[44.58]

Sample

Notes: Source: Author's calculations using data from California City Financial Transactions Reports, and CEDA data from 1992 to 2006, 1992 Census of Government data and 1990 Decennial Census data. The sample includes all general law cites in California with a municipal government in the 1992 Census of Governments, positive interest expenses in each year, and an appointive treasurer referendum put to voters in a future year. The variable Treasurer Appointive Referendum Pass takes a value of one if a local treasurer appointive referendum passed in a prior year in city $i$ in year $t$. The unit of observation is referendum-year. Each column presents the results from one regression specification. The main entries are coefficient estimates. The entries in parentheses are standard errors clustered at the city level. All models include city characteristics from the 1990 Census: Population Size, Percentage White, Percentage Black, Percentage Less Than Seventeen, Percentage Greater Than Sixty-Five, Percentage College Graduate, Percentage High School Graduate, Mayor-Council Form of Government, and Employment-Population Ratio. The models in columns (1) and (2) also control for a linear and cubic polynomial in vote share respectively. * indicates significantly different from zero at the $10 \%$ level of significance; ** indicates significantly different from zero at the $5 \%$ level of significance; *** indicates significantly different from zero at $1 \%$ level of significance. 
TABLE 8: The Effect of Appointive City Treasurers on City Borrowing Costs: FY2008 Debt Issue Sample, by Debt Issue Date

Dependent Variable $=$ Interest Rate on Outstanding Debt Issue

\begin{tabular}{|c|c|c|c|c|c|c|}
\hline \multirow{2}{*}{$\begin{array}{r}\text { Debt Issues }= \\
\text { Model }=\end{array}$} & \multicolumn{2}{|c|}{ All Debt Issues } & \multicolumn{2}{|c|}{ Debt Issued Before Referendum } & \multicolumn{2}{|c|}{ Debt Issued After Referendum } \\
\hline & $\begin{array}{l}\text { RD cubic } \\
(1)\end{array}$ & $\begin{array}{l}\text { RD cubic } \\
(2)\end{array}$ & $\begin{array}{c}\text { RD cubic } \\
\text { (3) }\end{array}$ & $\begin{array}{c}\text { RD cubic } \\
(4)\end{array}$ & $\begin{array}{c}\text { RD cubic } \\
(5)\end{array}$ & $\begin{array}{c}\text { RD cubic } \\
(6)\end{array}$ \\
\hline $\begin{array}{l}\text { Treasurer Appointive Referendum } \\
\text { Pass }\end{array}$ & $\begin{array}{l}-1.28 * \\
(0.68)\end{array}$ & $\begin{array}{l}-1.33^{* *} \\
(0.67)\end{array}$ & $\begin{array}{c}-2.32^{* *} \\
(0.91)\end{array}$ & $\begin{array}{c}-2.54 * * * \\
(0.91)\end{array}$ & $\begin{array}{c}1.17 \\
(1.10)\end{array}$ & $\begin{array}{c}1.36 \\
(1.04)\end{array}$ \\
\hline $\begin{array}{l}\text { Number of Observations } \\
1990 \text { Census Controls } \\
\text { Debt Issue Characteristic Controls }\end{array}$ & $\begin{array}{l}205 \\
\text { Yes } \\
\text { No }\end{array}$ & $\begin{array}{l}205 \\
\text { Yes } \\
\text { Yes }\end{array}$ & $\begin{array}{l}129 \\
\text { Yes } \\
\text { No }\end{array}$ & $\begin{array}{l}129 \\
\text { Yes } \\
\text { Yes }\end{array}$ & $\begin{array}{l}76 \\
\text { Yes } \\
\text { No }\end{array}$ & $\begin{array}{l}76 \\
\text { Yes } \\
\text { Yes }\end{array}$ \\
\hline $\begin{array}{l}\text { Baseline Dependent Variable: } \\
\text { Mean } \\
\text { [Standard Deviation] } \\
\{\text { Min, Max }\}\end{array}$ & $\begin{array}{c}5.06 \\
{[1.38]} \\
\{0.92,9.31\}\end{array}$ & $\begin{array}{c}5.00 \\
{[1.36]} \\
\{0.92,9.31\}\end{array}$ & $\begin{array}{c}5.33 \\
{[1.41]} \\
\{0.92,9.31\}\end{array}$ & $\begin{array}{c}5.33 \\
{[1.41]} \\
\{0.92,9.31\}\end{array}$ & $\begin{array}{c}4.45 \\
{[1.08]} \\
\{1.75,6.86\}\end{array}$ & $\begin{array}{c}4.45 \\
{[1.08]} \\
\{1.75,6.86\}\end{array}$ \\
\hline
\end{tabular}

Sample

Referendum Cities

Referendum Cities

Referendum Cities

Notes: Source: Author's calculations using data from California City Financial Transactions Reports from 2008, and CEDA data from 1995 to 2006,1992

Census of Government data and 1990 Decennial Census data. The sample includes all general law cites in California with a municipal government in the 1992 Census of Governments, positive interest expenses in each year, and an appointive treasurer referendum put to voters in a prior year. The variable Treasurer Appointive Referendum Pass takes a value of one if a local treasurer appointive referendum passed in a prior year in city $i$ in a prior year. The unit of observation is debt issue. Each column presents the results from one regression specification. The main entries are coefficient estimates. The entries in parentheses are standard errors clustered at the city level. All models include a cubic polynomial in vote share and city characteristics from the 1990 Census: Population Size, Percentage White, Percentage Black, Percentage Less Than Seventeen, Percentage Greater Than Sixty-Five, Percentage College Graduate, Percentage High School Graduate, Mayor-Council Form of Government, and Employment-Population Ratio. The models in columns (2), (4) and (6) also include controls for the type and term of the debt issue. * indicates significantly different from zero at the $10 \%$ level of significance; ** indicates significantly different from zero at the $5 \%$ level of significance; *** indicates significantly different from zero at $1 \%$ level of significance. 
TABLE A1: List of City Treasurer Appointive Referenda

\begin{tabular}{|c|c|c|c|c|c|c|c|}
\hline Date & City & Vote Yes & Vote No & Total Votes & $\begin{array}{l}\text { Percent in } \\
\text { Favor }\end{array}$ & $\begin{array}{l}\text { Referendum } \\
\text { Pass }\end{array}$ & $\begin{array}{l}\text { Joint Referendum with } \\
\text { Appointive Clerk }\end{array}$ \\
\hline 7-Nov-95 & Ontario & 1836 & 6846 & 8682 & 0.21 & No & \\
\hline 26-Mar-96 & Dunsmuir & 214 & 415 & 629 & 0.34 & No & \\
\hline 26-Mar-96 & Reedley & 1701 & 1379 & 3080 & 0.55 & Yes & \\
\hline 26-Mar-96 & Ukiah & 1651 & 1933 & 3584 & 0.46 & No & \\
\hline 26-Mar-96 & Orange & 8730 & 12428 & 21158 & 0.41 & No & \\
\hline 26-Mar-96 & San Clemente & 3495 & 6874 & 10369 & 0.34 & No & \\
\hline 26-Mar-96 & Brea & 3092 & 3878 & 6970 & 0.44 & No & \\
\hline 5-Nov-96 & Live Oak & 559 & 514 & 1073 & 0.52 & Yes & Yes \\
\hline 5-Nov-96 & Livermore & 8557 & 14374 & 22931 & 0.37 & No & \\
\hline 5-Nov-96 & Auburn & 1951 & 3226 & 5177 & 0.38 & No & \\
\hline 5-Nov-96 & Waterford & 602 & 897 & 1499 & 0.40 & No & \\
\hline 5-Nov-96 & Santa Paula & 2850 & 3553 & 6403 & 0.45 & No & Yes \\
\hline 3-Nov-98 & San Juan Bautista & 166 & 346 & 512 & 0.32 & No & \\
\hline 3-Nov-98 & Paso Robles & 2386 & 3486 & 5872 & 0.41 & No & \\
\hline 3-Nov-98 & Gonzales & 474 & 447 & 921 & 0.51 & Yes & \\
\hline 3-Nov-98 & Benicia & 2700 & 5943 & 8643 & 0.31 & No & \\
\hline 3-Nov-98 & Arroyo Grande & 2486 & 3615 & 6101 & 0.41 & No & Yes \\
\hline 8-Jun-99 & Manteca & 1967 & 1812 & 3779 & 0.52 & Yes & \\
\hline 2-Nov-99 & Livermore & 7842 & 5698 & 13540 & 0.58 & Yes & \\
\hline 7-Mar-00 & Waterford & 544 & 619 & 1163 & 0.47 & No & \\
\hline 7-Mar-00 & Santa Maria & 6348 & 7086 & 13434 & 0.47 & No & Yes \\
\hline 7-Nov-00 & Tehachipi & 889 & 1173 & 2062 & 0.43 & No & \\
\hline 7-Nov-00 & Woodland & 7715 & 7123 & 14838 & 0.52 & Yes & \\
\hline 7-Nov-00 & Portola & 298 & 459 & 757 & 0.39 & No & \\
\hline 5-Nov-02 & Turlock & 5881 & 6077 & 11958 & 0.49 & No & \\
\hline 5-Nov-02 & Signal Hill & 685 & 1125 & 1810 & 0.38 & No & \\
\hline
\end{tabular}




\begin{tabular}{|c|c|c|c|c|c|c|c|}
\hline 5-Nov-02 & Portola & 162 & 390 & 552 & 0.29 & No & \\
\hline 5-Nov-02 & Barstow & 1028 & 2427 & 3455 & 0.30 & No & \\
\hline 5-Nov-02 & Firebaugh & 265 & 306 & 571 & 0.46 & No & \\
\hline 5-Nov-02 & Paso Robles & 2606 & 3824 & 6430 & 0.41 & No & \\
\hline 5-Nov-02 & Wasco & 952 & 1096 & 2048 & 0.46 & No & \\
\hline 28-Jan-03 & South Gate & 2537 & 5409 & 7946 & 0.32 & No & \\
\hline 4-Nov-03 & Fontana & 1931 & 1234 & 3165 & 0.61 & Yes & \\
\hline 2-Mar-04 & Calistoga & 607 & 590 & 1197 & 0.51 & Yes & Yes \\
\hline 2-Nov-04 & Waterford & 990 & 779 & 1769 & 0.56 & Yes & \\
\hline 8-Nov-05 & Pittsburg & 4319 & 6016 & 10335 & 0.42 & Yes & \\
\hline
\end{tabular}


TABLE A2: Descriptive Statistics in 1992, by City Treasurer Appointive Referendum Status

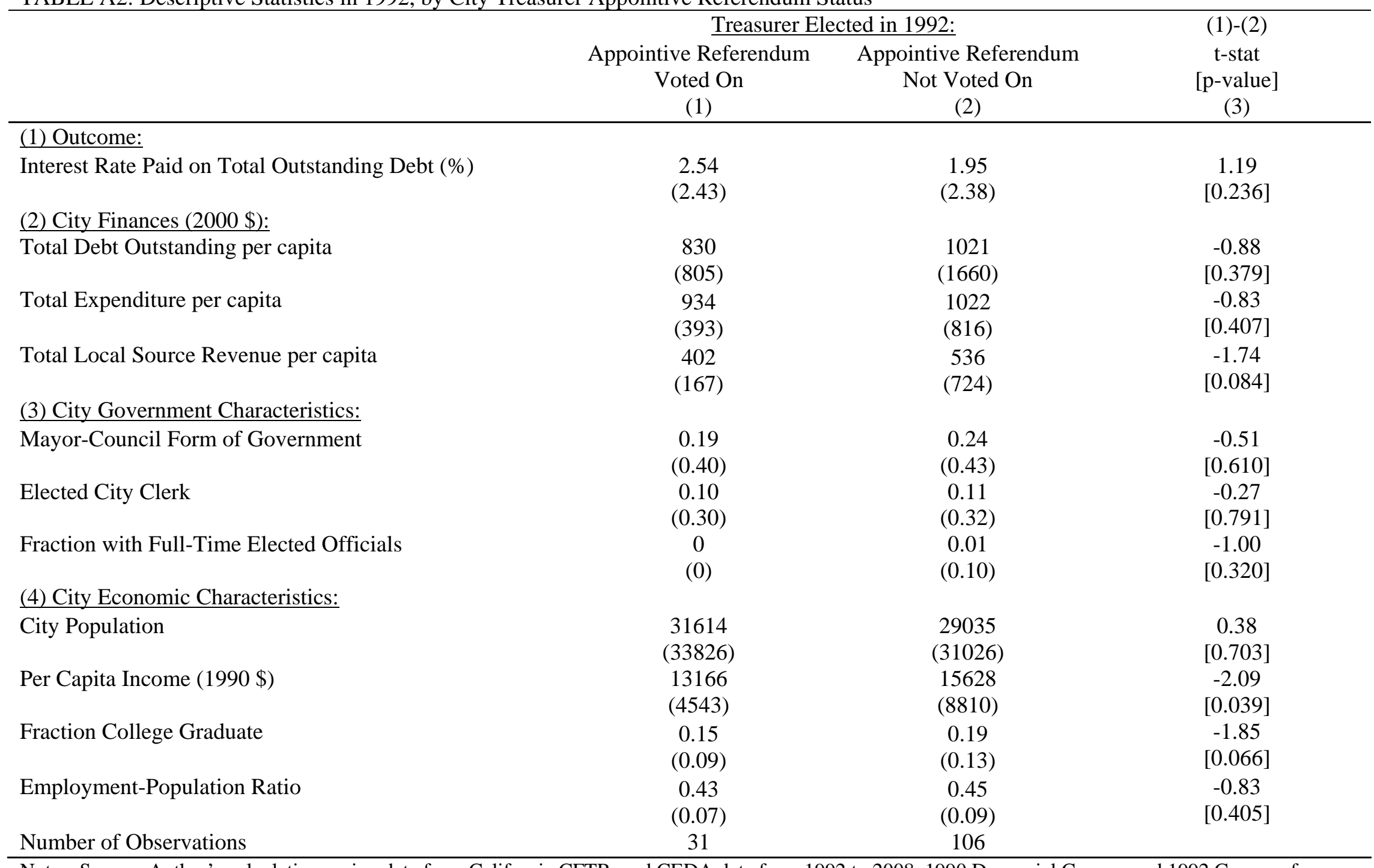

Notes: Source: Author's calculations using data from California CFTR, and CEDA data from 1992 to 2008, 1990 Decennial Census, and 1992 Census of 
Government data. The unit of observation is city. The main entries in column (1) present the mean of the selected variables for cities with elected treasurers and a referendum voted on. The main entries in column (2) present the mean of the selected variables for cities with elected treasurers and a referendum not voted

on. The standard deviations of the selected variable are presented in parenthesis in columns (1) and (2). The main entries in column (3) present the test statistics for a test of differences in means between column (1) and (2), with the p-value of the test presented in square brackets. The sample includes all general law cites in California with a municipal government in the 1992 Census of Governments and positive interest expenses in each year. All monetary values are expressed in 2000 \$ unless noted otherwise. The variables Interest Rate Paid on Total Outstanding Debt Total Local Source Revenue per capita, Total Expenditure per capita, and Total Debt Outstanding per capita are based on data from the California City Financial Transactions Reports (CFTR). The variables Mayor-Council Form of Government, Appointed City Clerk, and Full-Time Elected Officials are based on data from the 1992 Census of Governments. The variable City Population is based on data from the California E-1 Population Tables. The variables Per Capita Income, Fraction College Graduate, and Employment-

Population Ratio are based on data from the 1990 Decennial Census. Definition of the variables: Interest Rate Paid on Total Outstanding Debt (\%) is the ratio of total interest expenses divided by total debt outstanding Total Expenditure is the total expenditure to deliver city services; Total Local Source Revenue is total city revenue net of transfers from the Federal, State, and County governments; Total Debt Outstanding is the total stock of debt outstanding issued by the city; Mayor-Council Form of Government indicates whether or not the city has a directly elected mayor; Full-Time Elected Officials indicates whether or not the elected officials serve in a full-time capacity; City Population is the city population annually estimated by the California state Department of Finance; Per Capita Income is the per capita income in the city; Fraction College Graduate is the fraction of the population with a college degree in the city; and EmploymentPopulation Ratio is the ratio of employment to population in the city. 
TABLE A3: Baseline City Characteristics and Post-1992 Treasurer Appointive Referendums Outcomes

\begin{tabular}{lccc}
\hline & Mean & RD linear & RD cubic \\
& [Standard Deviation] & & \\
& $(1)$ & $(2)$ & $(3)$ \\
\hline Per Capita Income & 13166 & -255 & 1138 \\
Employment-Population Ratio & $(4543)$ & $(2471)$ & $(3347)$ \\
& 0.43 & -0.01 & -0.01 \\
Percent White & $(0.07)$ & $(0.04)$ & $(0.06)$ \\
Percent Black & 0.73 & -0.02 & 0.03 \\
& $(0.19)$ & $(0.11)$ & $(0.14)$ \\
Percent Less Than 17 & 0.03 & 0.00 & -0.03 \\
& $(0.04)$ & $(0.02)$ & $(0.03)$ \\
Percent Greater Than 65 & 0.28 & 0.00 & -0.05 \\
Percent College Graduate & $(0.05)$ & $(0.03)$ & $(0.04)$ \\
Percent High School Graduate & 0.12 & 0.00 & 0.05 \\
& $(0.05)$ & $(0.03)$ & $(0.04)$ \\
Population & 0.15 & -0.02 & 0.01 \\
& $(0.09)$ & $(0.05)$ & $(0.07)$ \\
Mayor-Council Government & 0.70 & -0.02 & -0.01 \\
& $(0.16)$ & $(0.09)$ & $(0.11)$ \\
Elected Clerk & 31614 & 12925 & $-38903^{*}$ \\
& $(33827)$ & $(18898)$ & $(21106)$ \\
& 0.16 & -0.01 & 0.04 \\
& $(0.40)$ & $(0.24)$ & $(0.32)$ \\
& 0.90 & $-0.30 *$ & -0.30 \\
& $(0.30)$ & $(0.17)$ & $(0.23)$ \\
\hline
\end{tabular}

Notes: Source: Author's calculations using data CEDA data from 1992 to 2006, 1990 Decennial Census data, and 1992 Census of Governments data.. The sample includes all general law cites in California with a municipal government in the 1992 Census of Governments, positive interest expenses in each year, and an appointive treasurer referendum put to voters in a future year. The variable Treasurer Appointive Referendum Pass takes a value of one if a local treasurer appointive referendum passed in a future year in city $i$. The unit of observation is city $(n=31)$. Each entry in columns (2) and (3) presents the results from one regression specification. The main entries are coefficient estimates. The entries in parentheses are standard errors. The models in columns (2) and (3) control for a linear and cubic polynomial in vote share respectively.* indicates significantly different from zero at the $10 \%$ level of significance; ** indicates significantly different from zero at the $5 \%$ level of significance; $* * *$ indicates significantly different from zero at $1 \%$ level of significance. 
FIGURE 1: Weekly Municipal Bond and Note Market Interest Rates, 1996-2006

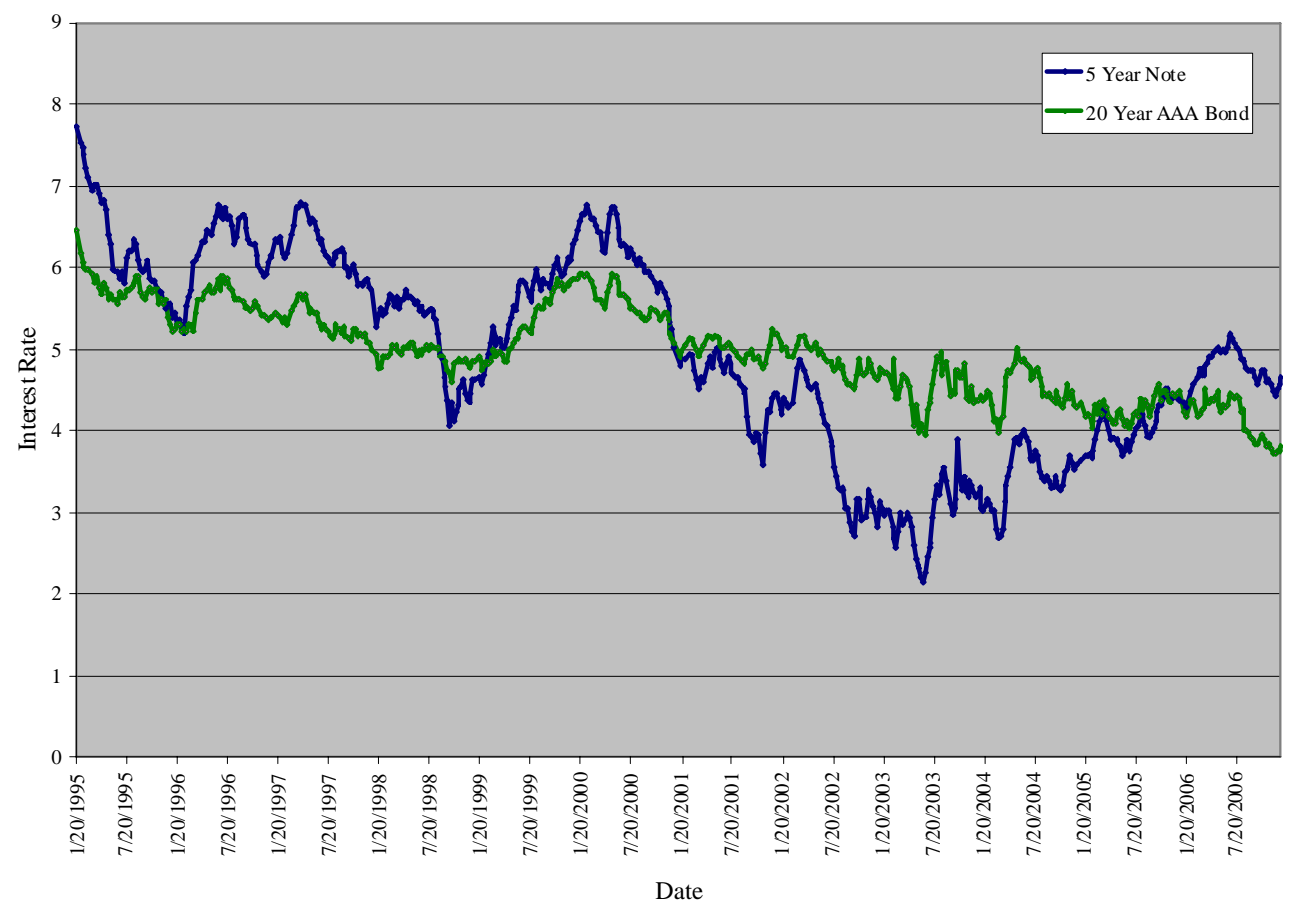

Notes: Source: Author's calculations using data from Global Financial Database - US Municipal Government Bond Yields.

FIGURE 2: Appointive Treasurer Referendum Vote Distribution

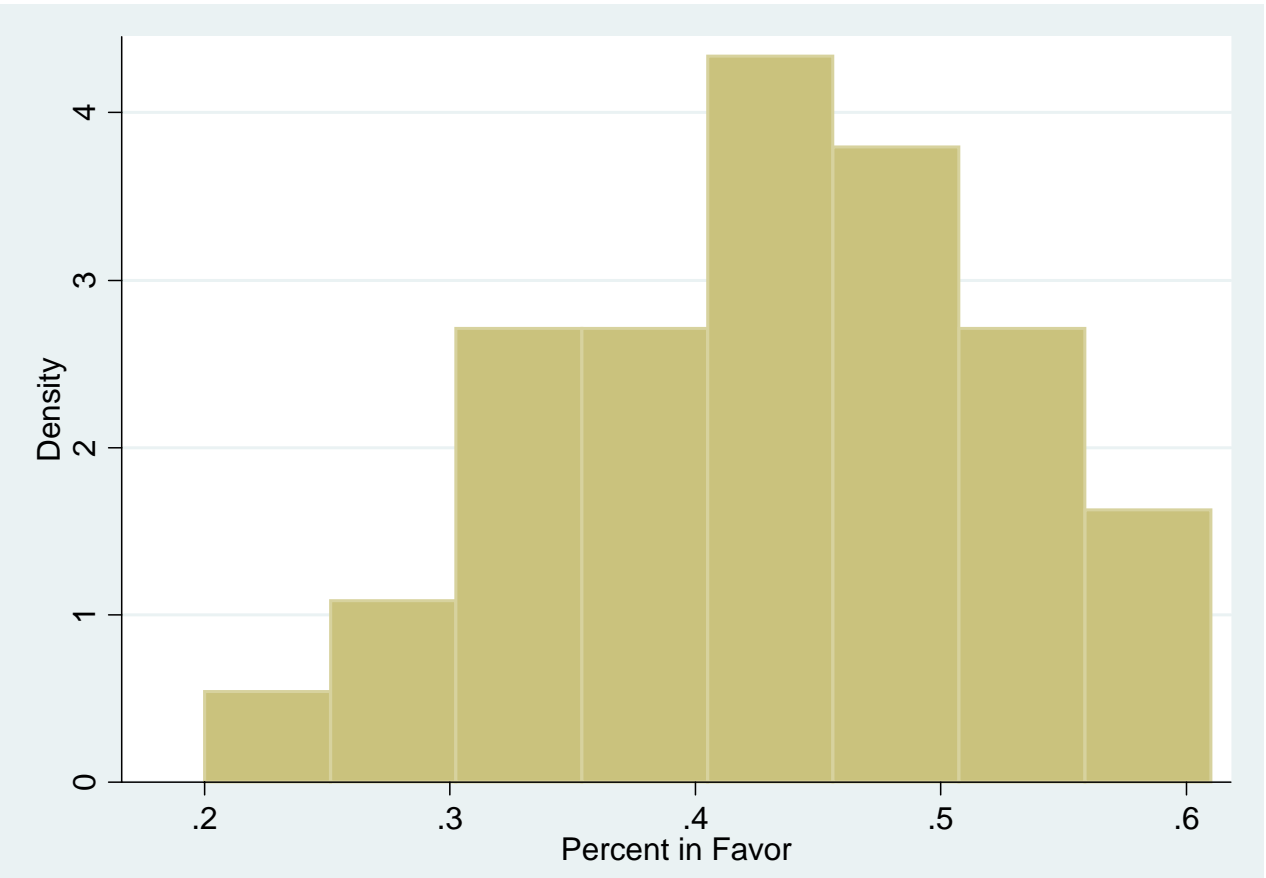

Notes: Source: Author's calculations using data from California Elections Data Archive (CEDA) data from 1995 to 2006. 
FIGURE 3: Treasurer Appointive Effect

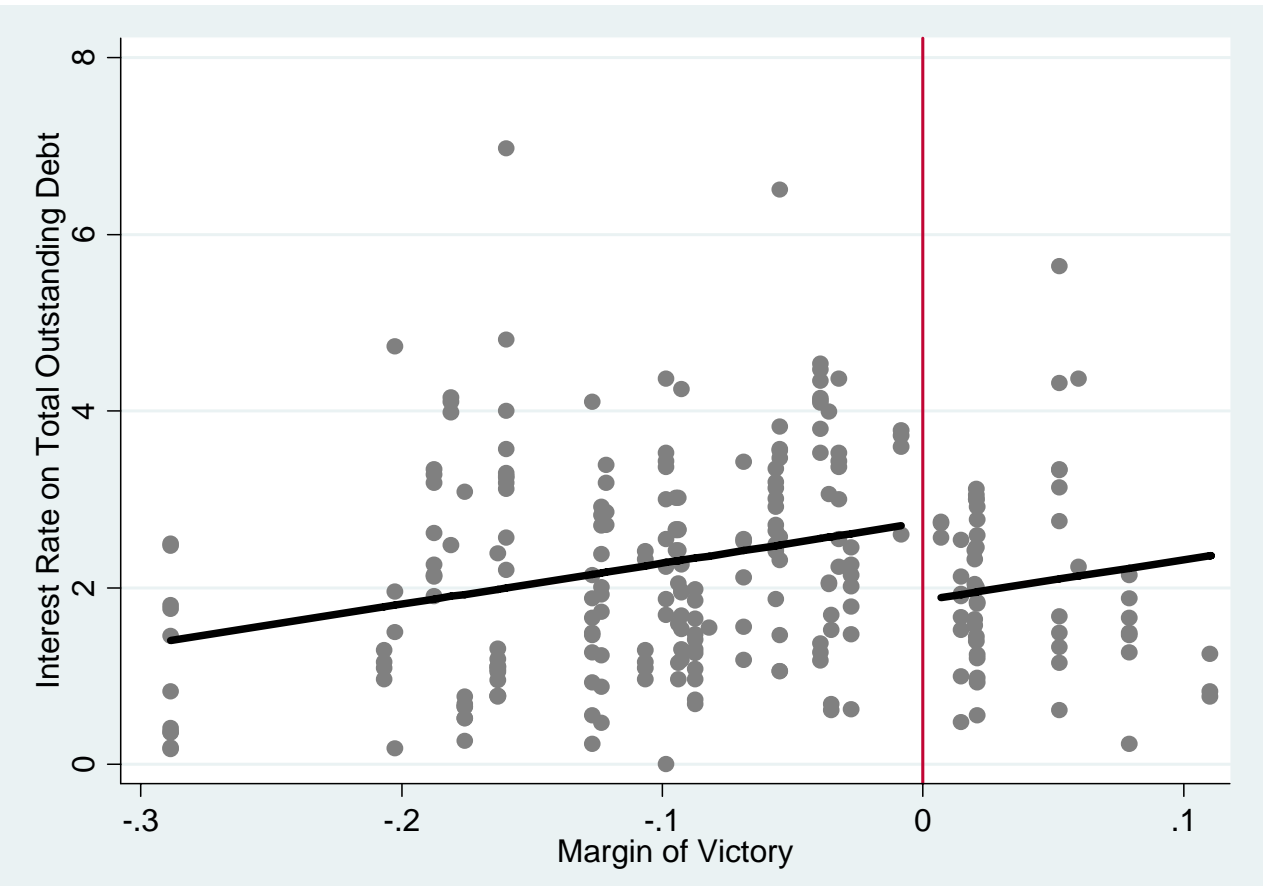

Notes: Source: Author's calculations using data from California City Financial Transactions Report, and CEDA data from 1992 to 2008. The sample includes all general law cites in California with a municipal government in the 1992 Census of Governments, positive interest expenses in each year, and an appointive treasurer referendum put to voters in a prior year. The figure plots the Interest Rate Paid on Total Outstanding Debt by the margin of victory in the treasurer appointive referendum. The line plots the predicted values of a regression of the interest rate on a referendum pass indicator, and a linear polynomial in referendum vote share. 
FIGURE 4: Treasurer Appointive Effect Prior to Treasurer Appointive Measure Vote

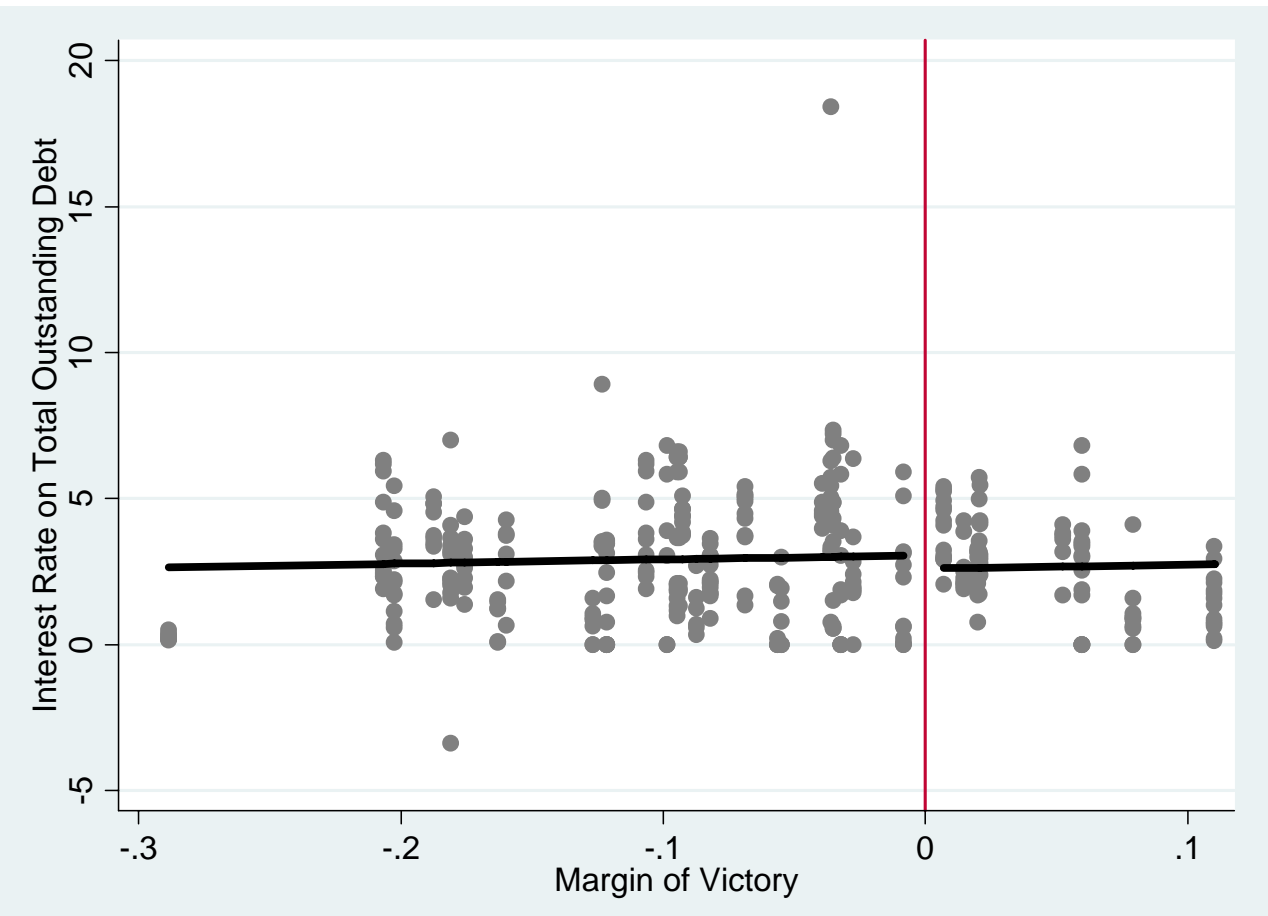

Notes: Source: Author's calculations using data from California City Financial Transactions Report, and CEDA data from 1992 to 2008. The sample includes all general law cites in California with a municipal government in the 1992 Census of Governments, positive interest expenses in each year, and an appointive treasurer referendum put to voters in a future year. The figure plots the Interest Rate Paid on Total Outstanding Debt by the margin of victory in the future treasurer appointive referendum. The line plots the predicted values of a regression of the interest rate on a future referendum pass indicator, and a linear polynomial in referendum vote share. 
FIGURE 5: Appointive Effect on Fiscal Policy

\section{(a) Total Expenditure}

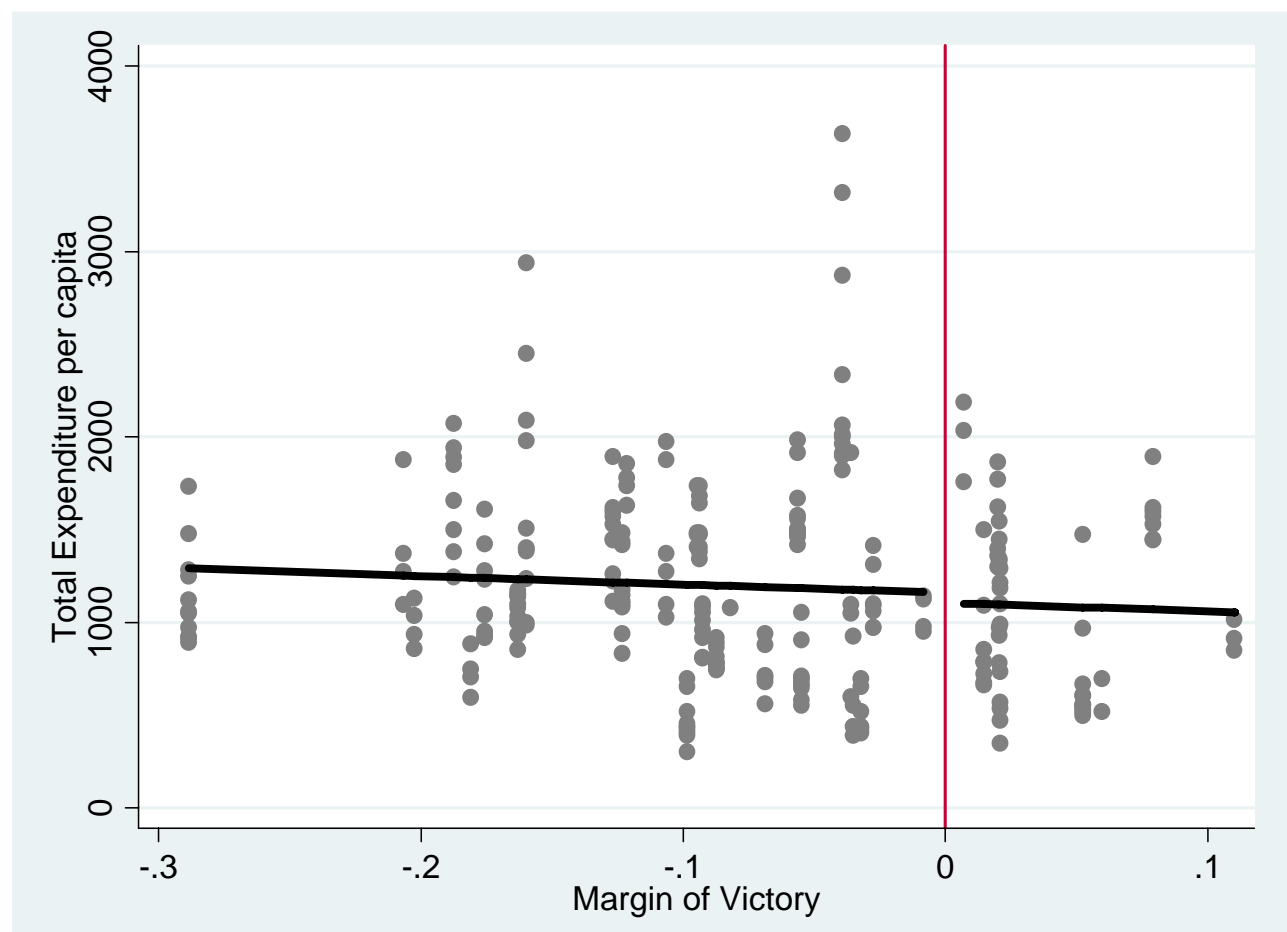

Notes: Source: Author's calculations using data from California City Financial Transactions Report, and CEDA data from 1992 to 2008. The sample includes all general law cites in California with a municipal government in the 1992 Census of Governments, positive interest expenses in each year, and an appointive treasurer referendum put to voters in a prior year. The figure plots the Total Expenditure per capita by the margin of victory in the treasurer appointive referendum. The line plots the predicted values of a regression of the Total Expenditure per capita on a referendum pass indicator, and a linear polynomial in referendum vote share. 
(b) Total Local Source Revenue

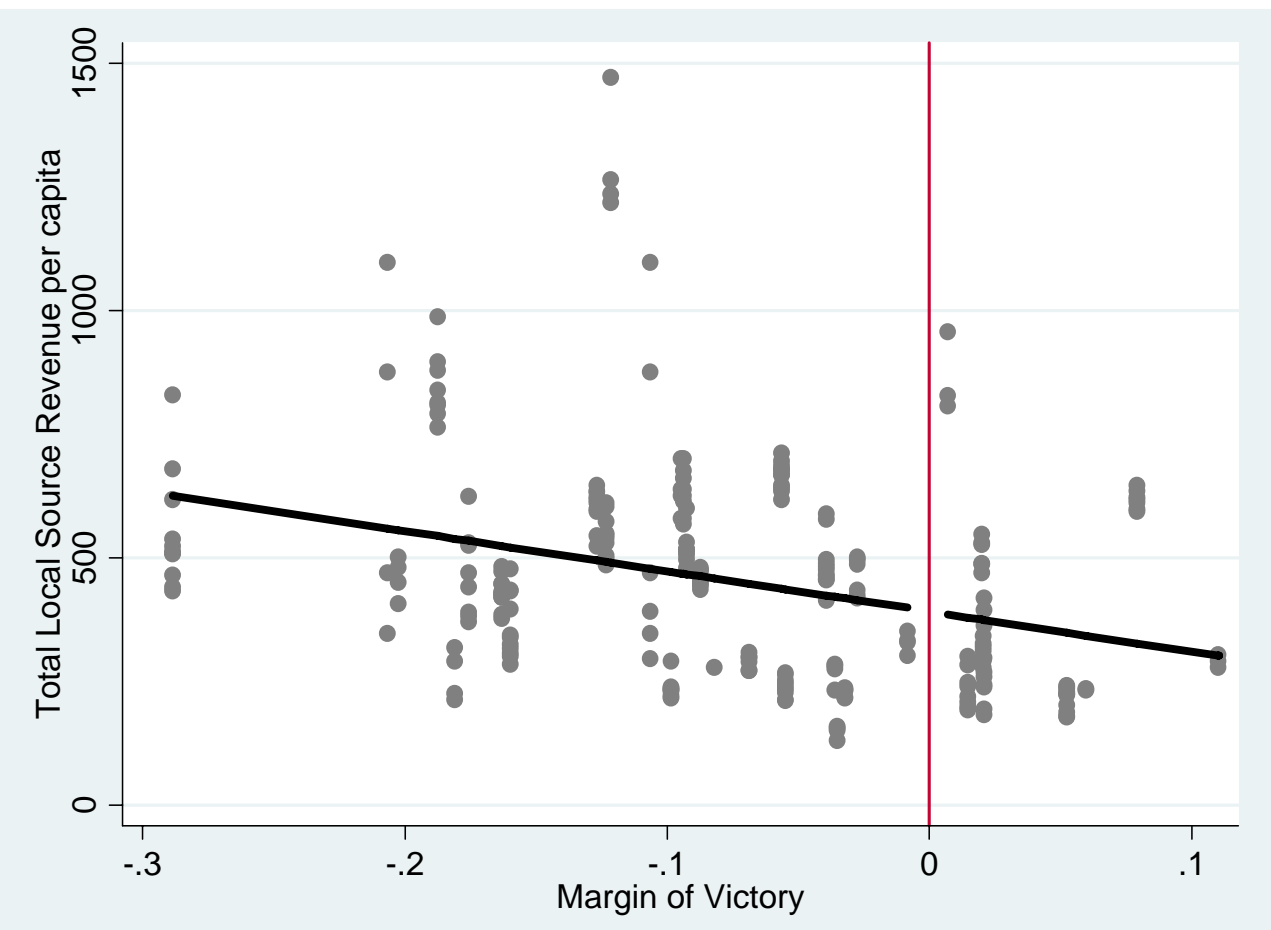

Notes: Source: Author's calculations using data from California City Financial Transactions Report, and CEDA data from 1992 to 2008. The sample includes all general law cites in California with a municipal government in the 1992 Census of Governments, positive interest expenses in each year, and an appointive treasurer referendum put to voters in a prior year. The figure plots the Total Local Source Revenue per capita by the margin of victory in the treasurer appointive referendum. The line plots the predicted values of a regression of the Total Local Source Revenue per capita on a referendum pass indicator, and a linear polynomial in referendum vote share. 


\section{(c) Total Debt Outstanding}

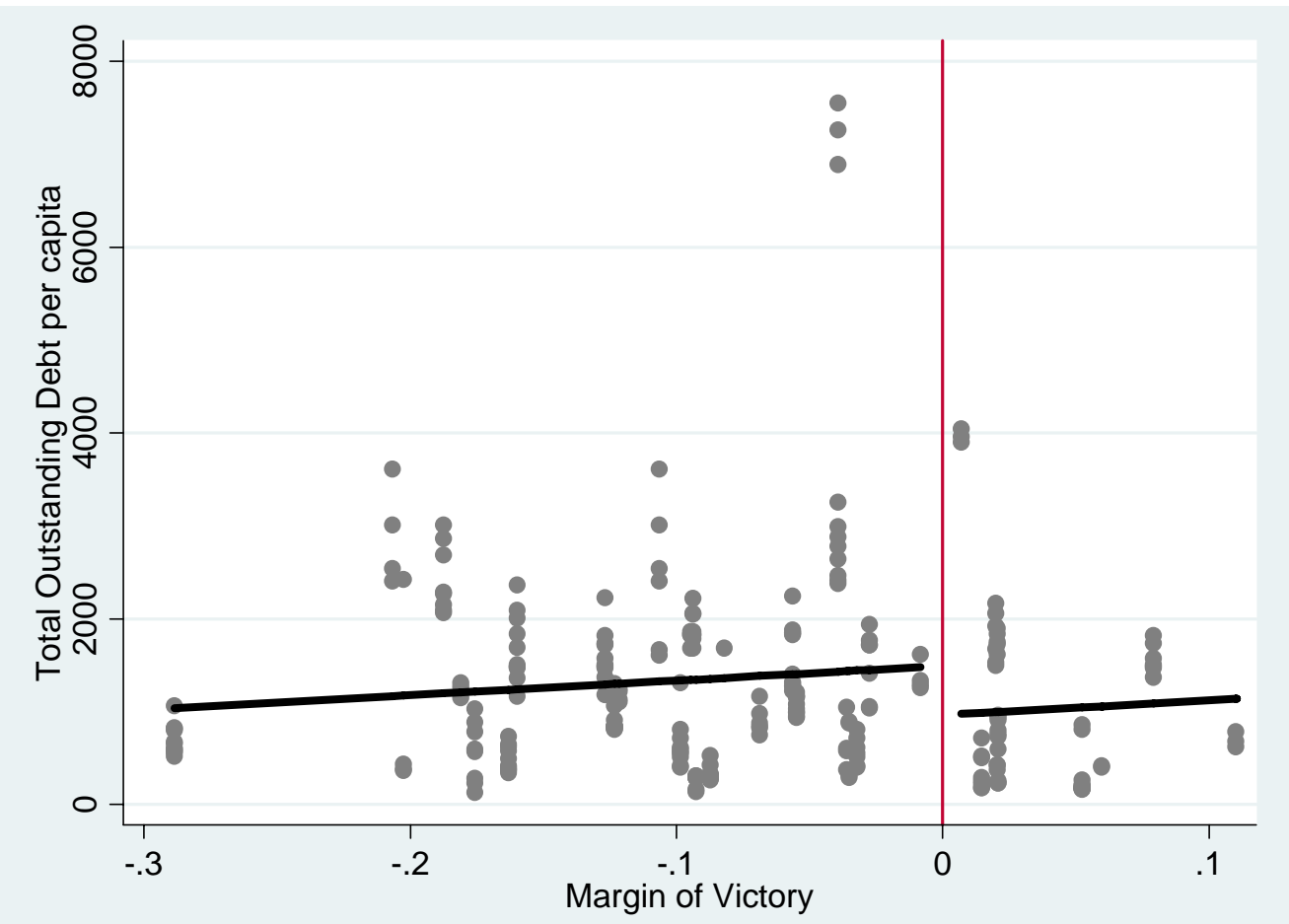

Notes: Source: Author's calculations using data from California City Financial Transactions Report, and CEDA data from 1992 to 2008. The sample includes all general law cites in California with a municipal government in the 1992 Census of Governments, positive interest expenses in each year, and an appointive treasurer referendum put to voters in a prior year. The figure plots the Total Debt Outstanding per capita by the margin of victory in the treasurer appointive referendum. The line plots the predicted values of a regression of the Total Debt Outstanding per capita on a referendum pass indicator, and a linear polynomial in referendum vote share. 